\title{
An Important Space in the Traditional Turkish Life Culture: "Başoda" in Ottoman Period Nicosia Houses
}

\author{
Geleneksel Türk Yaşam Kültüründe Önemli Bir Mekân: \\ Osmanlı Dönemi Lefkoşa Türk Evlerinde "Başoda"
}

\section{Zihni Turkan * ${ }^{\circledR}$, Ergül Koşanlar* (1)}

\begin{abstract}
The traditional Turkish House was formed with the Turkish life culture, beginning with the tent in Central Asia; took its final form in the $19^{\text {th }}$ century and became the typical housing character in Anatolia and other geographies under the sovereignty of the Ottomans. The planning scheme of the Turkish House, with an authentic characteristic, is designed with storeys and their use, plain front, oriel window, slanted roof with wide wooden eaves, hall, multi-functional rooms, and yard. Besides all these features, the largest and most important room of the house, forming an important characteristic, the Başoda (Mainroom) is designed by assessing the value given to guests in the living culture. The Başoda, situated in the most advantageous position in the house regarding illumination, ventilation, and scenery, also has an authentic quality in its interior elements of flooring, walls and ceiling, material, form, and ornamentation, and it in a way it reflects the traditional life philosophy. Having an important place in the rich cultural heritage of the Ottoman Period in Cyprus (1571-1878), 19 ${ }^{\text {th }}$ century Turkish Houses are designed by Turkish life culture, as in other geographies, and the Başodas are designed meticulously for guests, thus forming an important characteristic. Findings of this study, the importance given to guests in the Traditional Turkish Houses shaped with the traditional life culture, can be observed in the Başodas of $19^{\text {th }}$ century houses in Cyprus.
\end{abstract}

\section{Keywords}

Nicosia, Cyprus, Turkish, Space, Guest

\section{Öz}

Geleneksel Türk Evi, Türklerin Orta Asya'daki göçebe yaşamlarındaki çadırdan itibaren Türk yaşam kültürüyle biçimlenmiş; son şeklini 19. yüzyılda alarak, Anadolu'da ve Osmanlı egemenliği altındaki diğer coğrafyalarda tipik ev karakterini teşkil etmiştir. Türk Evi’nde, önemli bir karakteristik teşkil eden plan şeması, kat adedi ile katların kullanımı, yalın cephe, cumba, eğimli çatı ile geniş ahşap saçaklar, sofa, çok amaçlı odalar ve avlunun yanı sıra evin en büyük ve en önemli odası olan Başoda, geleneksel yaşam kültüründe misafire verilen değerle tasarlanmıştır. Evin, aydınlatma, havalandırma ve manzara açılarından en avantajlı konumunda yer alan Başoda'nın iç mekân ögeleri olan döşeme, duvar ve tavanları, malzeme, biçim ve süsleme olarak da özgün niteliğe sahiptir ve âdeta geleneksel yaşam felsefesini yansıtmaktadır. Kıbrıs'ın Osmanlı Dönemine (1571-1878) ait zengin kültür mirası içerisinde önemli bir yere sahip 19. yüzyıl Türk Evleri, diğer coğrafyalardaki

* Correspondence to: Zihni Turkan (Assoc. Prof. Dr.), Near East University, Architecture, Lefkoşa, North Cyprus. E-mail: zihni.turkan@neu.edu.tr ORCID: 0000-0001-5266-5192

** Ergül Koşanlar (Intr. Arch. M.A.), Near East University, Graduate School of Applied Science, Lefkoşa, North Cyprus. E-mail: e_usluer@hotmail.com ORCID: 0000-0002-2615-3940

To cite this article: Turkan, Zihni, Kosanlar, Ergul. "An Important Space in the Traditional Turkish Life Culture: "Başoda" in Ottoman Period Nicosia Houses." Art-Sanat, 17(2022): 497-527. https://doi.org/10.26650/artsanat.2022.17.930610 
örnekleri gibi Türk yaşam kültürüne göre biçimlenmiş ve Başodaları da misafir için özenle düzenlenerek tasarlanmıştır. Araştırmamızda gerçekleştirdiğimiz literatür taraması ve alan çalışmaları sonucunda elde edilen bulgular, geleneksel yaşam kültürü ile biçimlenen Geleneksel Türk Evleri'nde misafire verilen önemi, Anadolu dışındaki coğrafyaların yanı sıra Kıbrıs'taki 19. yüzyıl evlerinin başodalarında da ortaya çıkarmaktadır.

Anahtar Kelimeler

Lefkoşa, Kıbrıs, Türk, Mekân, Misafir

\section{Genisletilmis $\ddot{O}_{z e t}$}

Temeli Türklerin Orta Asya'daki göçebe yaşamındaki çadıra dayanan Türk Evi kavramı, Türk yaşam kültürü ile biçimlenerek, ilk kez 17. yüzyılda ortaya çıkmış ve tüm karakteristikleriyle gelişimini tamamlayarak, 19. yüzyılda son şeklini almıştır. Anadolu dişında, Osmanlı hâkimiyeti altındaki topraklar ile Akdeniz ve Ege'deki adaların başkentlerinde tipik ev karakterini teşkil eden Geleneksel Türk Evi; özgün plan şeması, toprakla ilişki kurulan avlusu, ev halkının buluştuğu sofası, oturma, yatma, yemek yeme, yıkanma gibi işlevlere hizmet eden çok amaçlı odaları, sokağa çıkma yapan cumbası, geniş ahşap saçaklarla kuşatılmış eğimli çatısı gibi özellikleriyle dünya mimari literatürüne girmiş ve tarihî konut mimarisinde önemli bir yere sahip olmuştur. Geleneksel Türk Evi'nin her bölümünün her mekânının işlevlenmesinde olduğu gibi evin en büyük ve en önemli odası olan Başoda da Türklerin misafire verdikleri önemle özenle tasarlanmış ve karakteristik oluşturmuştur.

Misafir, Türklerin geleneksel yaşam kültürlerinde hep önemli olmuş; en iyi şekilde rahat ettirilmek, ağırlanmak ve hoş tutulmak için özel kılınan mekânlarda konuk edilmiştir. Bu amaçla misafir odası olarak düzenlenen Başoda, evin, aydınlatma, havalandırma ve manzara açılarından en avantajlı konumunda yer almıştır. Başoda'nın kapısından itibaren, iç mekân tasarım ögeleri olan döşeme, duvar ve tavanları, malzeme, biçim ve süsleme olarak özgün niteliğe sahip şekilde tasarlanarak evin diğer mekânlarından farklılık yaratılmış ve böylece bu odayla geleneksel yaşam felsefesi yansıtılmıştır. Çok büyük evlerde, köşklerde ve saraylarda ise misafir odası, kadınlar ve erkekler için ayrı olarak tasarlanmış; Harem ve Selâmlık diye isimlendirilmiştir.

1571 yılında Kıbrıs'ta başlayan Osmanlı döneminde de adada, Türk Mimari eserleri olarak camiler, tekkeler, hanlar, hamamlar, çeşmeler, kaleler ve evler inşa edilmiştir. Bu eserler arasında önemli bir yere sahip olan 19. yüzyıl Türk Evleri, diğer coğrafyalardaki örnekleri gibi Türk yaşam kültürüne göre biçimlenmiş ve Başodaları da misafire verilen önemle özel olarak düzenlenmiştir. Hâlen adanın başkenti Lefkoşa'da, suriçi tarihî dokusunda, dar sokaklar boyunca sıralanmış, yüzyılı aşmış geçmişleriyle birer kültür mirası olan ve çalışmamızda örneklediğimiz, Türk Evleri, 19. yüzyılın sonlarında inşa edilmiş; günümüze kadar farklı amaçlarla kullanılmış ve yakın geçmişte restore edilerek işlevlendirilmiştir. Lefkoşa suriçinin iki önemli mahallesi olan Arabahmet ve Selimiye Mahalleleri'nde yer alan örnek Türk Evleri; Bohcalian Ko- 
nağ1, Derviş Paşa Konağı, Saçaklı Ev, Kadı Menteşoğlu Konağı ve Küçük Mehmet Binası, günümüzde lokanta, müze, kültür-sanat merkezi ve ofis gibi farklı işlevlerle kullanılmaktadır. Bu evlerin en büyük ve en önemli odaları olan Başodaları; evin ya manzaraya hakim bir köşe bölümünde, veya sokağa üç yönde cephelenen çıkmalı odasında yer almaktadır. Başodalar, çıkmalı odalarda, çıkmanın üç yönüne açılan pencerelerle; köşe konumlu odalarda ise iki yöne açılan pencereler ve tepe pencereleri ile gün 1şığı, doğal hava ve manzara açılarından evin en avantajlı odası hâline getirilmişlerdir.

Başodaların ayrıcalığı, kapılarından itibaren başlamaktadır. Çift kanatlı ahşap kapıların kanatları, üzerinde oluşturulan kenarları profilli, farklı geometrilerdeki panolar ve ahşap kabartma motiflerle süslenmiştir. Yan yana sıralanmış dikdörtgen biçimli, çift kanatlı ahşap pencereleri, ahşap panjurludur. Pencereler, kenarları profilli geniş ahşap pervazlarla kuşatılmıştır. Pervazlar, oda cephelerinde, yatay konumda devam ettirilerek pencerelerin aralarındaki duvar yüzeylerinde panolar oluşturulmuştur. Pencerelerin üst hizalarında yer alan dar ahşap raflar, oda cepheleri boyunca yatayda uzatılarak bir üst çizgi oluşturulmuştur.

Duvarlarda görülen ahşap, camlı kapaklı, raflı nişler yanı sıra, özellikle yarım daire planlı ve yarım daire kavsaralı, motiflerle biçimlendirilmiş alınlıkla taçlandırılmış lambalık (çiçeklik) nişleri, Başodaların simgeleri olmuştur. İçlerine mermer plak yerleştirilmiş lambalık nişleri ya çeşitli renklerde boyanarak motiflerle süslenmiş ya da ahşapla kaplanmıştır. Kaplama ise tornalı ahşaplarla bölümlere ayrılmıştır.

Başodaların döşemeleri, yan yana sıralanmış, boyalı veya cilalı ahşaplar ya da kare biçimli yerel taş plaklarla kaplanmıştır. Şaşırtmalı veya diyagonal olarak dizilen taş plaklar, duvarlara paralel dizilen taş plak sıraları ile de çerçevelenerek döşemeye dekor yapılmıştır. Bazen de döşemenin ortasına, farklı geometrik biçimlerdeki taş plaklarla göbek oluşturularak döşemede dekor zenginleştirilmiştir. Genellikle ahşap kaplı tavanlar, profilli ince ahşap çıtalarda yapılmış geometrik biçimlerle işlenmiş, tavan duvar birleşimleri, geniş ahşap pervazlarla kuşatılmış, tavanın ortasına da çeşitli oyma veya kabartma motiflerle biçimlendirilmiş ahşap göbek yerleştirilmiştir. Başodaların dikdörtgen biçimli tavanları ise ahşap pervazlarla kuşatılarak kare ve dikdörtgen bölümlere ayrılmış ve her bölüme ahşap çıtalarla işleme yapılmıştır.

Günümüzde, restore edilmiş olan Lefkoşa' daki Türk Evleri’nin Başodaları, özgün kimliklerine göre işlevlendirilerek yaşatılmakta ve özgün tasarımları ile Türk yaşam kültüründe misafire verilen önemi yansıtarak kültür miraslarımızı geçmişten geleceğe taşımaktadırlar.

Bu makalenin amac1, geleneksel Türk yaşam kültüründe misafire verilen önem ile Geleneksel Türk Evleri’nde bir karakteristik teşkil eden ve evin en özel mekânı olan 
Başoda'nın oluşumunu, Lefkoşa'daki Osmanlı dönemi 19. yüzyıl evleri örnekleriyle, iç mekân tasarım ögelerini oluşturan duvar, döşeme, tavanların, malzeme, biçim ve süsleme detaylarının analizi ile irdeleyip önemini ortaya koymaktır. Araştırmamızın sınırlılıklarını ise Türk Evi'nde Başoda kavramı, Lefkoşa 19. yüzyıl evleri ile alan çalışmamıza örnek olarak seçtiğimiz Kıbrıs'ın Osmanlı döneminden günümüze ulaşan ve restore edilerek işlevlendirilmiş Lefkoşa Türk Evlerinin Başodalarının iç mekân tasarımları oluşturmaktadır. 


\section{Introduction}

Its formation was based on their shelter in Central Asia, the tent, the Traditional Turkish House was developed with the Turkish life culture and it first appeared in the $17^{\text {th }}$ century in the form it is known at present, and completed its development in the $19^{\text {th }}$ century Turkish Houses, having unique characteristics, formed the typical house character in the lands under Ottoman rule, and in the capitals of the islands in the Aegean and the Mediterranean.

Being of a single floor in general, and even with multi-floor houses, still having a basic one floor (the upper floor), with an authentic plan scheme, and with a yard, the Turkish House has an important place in the history of housing architecture with its oriel window projecting toward the street, with its multi-functional rooms, its Başoda (Mainroom), and its slanting roof surrounded by wide, timber eaves.

During the Ottoman Period in Cyprus, which began in 1571, mosques, inns, baths, convents, fountains, castles, and houses were built as works of Turkish Architecture. Traditional Turkish Houses, having an important place among these works, still survive at present within the historical city texture of the walled city of capital Nicosia, resisting time, and displaying traces of their periods.

Highlighting the value and importance given to guests in the Turkish life culture, the Başoda, one of the characteristics of Traditional Turkish Houses, takes place in the Turkish Houses in Nicosia as an important place, just like in other geographies outside the island. Throughout the time from their date of construction to the present, Nicosia Turkish Houses have suffered from inter-communal clashes, migration, bad usage, demographic changes, and insensible alterations, and some of them have been left to their destiny by being functionless. Very few of these houses have been expropriated and taken under state protection, and have been functional after renovation. Research and documentation of the Başoda, an important reflection of Turkish life culture, in these Traditional Turkish Houses dating from the $19^{\text {th }}$ century to form a reference for the future makes this study important.

In this study, it is aimed to examine and document in detail, all the elements, materials, form and ornamentations constituting the interior design of the Başoda, from selected Ottoman Period Turkish Houses in Nicosia, which is the most important room and characteristic of the Traditional Turkish Houses.

The quality of the Başoda, constituting an important characteristic of the Traditional Turkish Houses, and the Başodas (Mainrooms) of the Nicosia Turkish Houses selected for the field study, form the content of this study.

It is believed that this study on the Başoda making up an important characteristic Turkish life culture and of the Ottoman Period Turkish Houses, will provide a ref- 
erence for future studies about Traditional Turkish Houses and historical housing architecture during the Ottoman Period.

\section{Methodology}

The qualitative research method is used in this study. Initially, the formation of the concept of Traditional Turkish House was researched, as well as spatial features forming characteristics, and the concept of guests, which has an important place in Turkish life culture, and the special space Başoda, designed for guests, were researched through a literature review of written sources.

At a later stage literature review was carried out on the Turkish Houses in Nicosia, dating to the Ottoman Period of Cyprus, from local resources and information was collected. Five sample houses were selected from among the $19^{\text {th }}$ century Ottoman Period Nicosia houses for field study. Information was collected on the dates of the selected houses from books, articles, and other documents. Later, a field study was carried out in the selected houses through observation and examination. The places of Başodas in the houses, their plans and their contemporary usage were established, the interior space elements of their floors, walls, and ceilings, such as material, shape, and ornamentation, were studied and documented. The exterior and interior of houses and Başodas were photographed and the study was supported with visuals.

Finally, based on the findings of the field study, the characteristics Başodas of Nicosia Turkish Houses were assessed, their common characteristics were documented, and the importance of the Başoda in the Ottoman Period Turkish Houses in Nicosia was established.

\section{Başoda in the Turkish House}

The multi-functional usage and common space among tents, which were the housing of the nomadic lifestyle of Turks in Central Asia, formed the basis in the planning of the Traditional Turkish Houses. The relationship with the earth in this lifestyle also created the importance of the yards in houses in permanent settlements ${ }^{1}$.

All the spaces in the Traditional Turkish Houses and their authentic functions that they serve, which took a place in architectural literature by being shaped with the Turkish life culture and gained a characteristic, were designed with the traditional lifestyle of their users, and with their cultural effects. These spaces have gained authentic identities with their interior designs, furnishings, and decorations.

In other words, the formation of the Turkish House and its rooms are closely related to the characteristics of social structure and came into being as the shaping of general notions ${ }^{2}$.

1 Önder Küçükerman, Kendi Mekânının Arayışı İçinde Türk Evi (İstanbul: Türkiye Turing ve Otomobil Kurumu Yayını, 1991), 80.

2 Küçükerman, Kendi Mekânının Arayışı İçinde Türk Evi, 48, 73. 
Having multi-purpose usage with the daily life activities, rooms in the Turkish House are sufficient for the vital functions of the nuclear family, such as sleeping, sitting, washing, eating. Multi-purpose rooms also define a unique lifestyle ${ }^{3}$. The halls, into which rooms open, are the meeting place where common activities are realized and are the common spaces in the life culture. The notions of family and neighborhood had a very important place in the daily life of Turkish life culture, and forming a cultural richness, is emphasized in the organization of Turkish Houses and have been effective in the design of interior spaces.

In the traditional life of Turks, guests have always been considered as sent by God, and it was always desired to keep the guest merry, make him/her feel comfortable, and be served well. Therefore, the most beautiful and splendid room of the house was designed as the guest room and named the Başoda ${ }^{4}$. Being in the most advantageous location of the house, the Başoda was either a corner room facing more than a street or a square or protruding to the street. The Başoda is the largest room of the house, having the most sunlight, air, and a view of the scenery. Displaying a difference with its design, material, and ornamentation, starting from its door, the Başoda, valued with its flooring, skylights, lamp niches, and ornamented timber ceiling, actually reflects the importance given the guest. In very large houses, mansions, and palaces, guests rooms were planned for men and women separately, as a harem and 'selamlik' (for the reception of male friends $)^{5}$.

\section{Başoda (Mainroom) In Nicosia Turkish Houses}

The Traditional Turkish House has been the typical house character in the capital of the island Nicosia during the Ottoman Period of Cyprus (1571-1878), as it was in Anatolia and other places under Ottoman rule ${ }^{6}$.

Despite all unfavourable developments, Nicosia Turkish Houses, dating back to the $19^{\text {th }}$ Century, form the historical street texture within the historical walled city by lining up side by side along narrow streets ${ }^{7}$.

3 Cengiz Bektaş, Türk Evi (İstanbul: Yapı Kredi Yayınları, 1996), 111; Sedad Hakkı Eldem, Turkish House Ottoman Period III (İstanbul: Türkiye Anıt Çevre Turizm Değerlerini Koruma Vakfı Yayını, 1987), 15; Önder Küçükerman ve Şemsi Güner, Anadolu Mirasında Türk Evleri (İstanbul: T.C. Kültür Bakanlığı Yayını, 1995), 87, 91; Doğan Kuban, Türk Hayat'lı Evi. (İstanbul: T. C. Ziraat Bankası Kültür Yayını, 1995), 106, 113.

4 Doğan Hasol, Ansiklopedik Mimarlık Sözlüğü (İstanbul: Yapı-Endüstri Merkezi Yayını, 1993), 72, 73; Hülya Yürekli ve Ferhan Yürekli, Türk Evi Gözlemler-Yorumlar (İstanbul: Yapı-Endüstri Merkezi Yayını, 2005), 16

5 Kuban, Türk Hayat'lı Evi, 150, 151.

6 Sedad Hakkı Eldem, Turkish House Ottoman Period I (İstanbul: Türkiye Anıt Çevre Turizm Değerlerini Koruma Vakfı Yayını, 1984), 16; Louis Salvator, Kıbrıs ’n Başkenti Levkosia, çev. Vur Yektaoğlu (Lefkoşa: Galeri Kültür Yayınları, 2012), 20.

7 Anonymous, Kıbrıs'ta Türk Eserleri (Lefkoşa: Kıbrıs Türk Federe Devleti Eğitim, Gençlik, Kültür ve Spor Bakanlığı Eski Eserler ve Müzeler Dairesi Müdürlüğü Yayını, 1982), 32; Zihni Turkan, "The Place of Turkish Culture of The Life in Housing Design: Example of Turkish Houses in Cyprus During the Ottoman Period", The Turkish Online Journal of Design, Art and Communication 6/3 (2016), 344. 
Making up an important space with its characteristics, the Başoda was designed for guests as the most valuable room of the house, and as a symbol of Turkish life culture in Cyprus, just like all the other space in the house ${ }^{8}$. The place and importance of the Başoda in the Traditional Turkish House can be examined with the details of internal elements in examples from Nicosia Turkish Houses as described below:

\section{3.a. Bohcalian Mansion}

The mansion is in the walled city of Nicosia, in Şehit Salahi Şevket Street (Victoria Street), within the Arabahmet Neighborhood, which accommodates a rich historical texture ${ }^{9}$. Addressed at number 53, the mansion was built towards the end of the $19^{\text {th }}$ century. It is understood from date on its door that it underwent some alteration in 1907. An important sample of Nicosia Turkish Houses, the mansion is of a two-floor plan with a yard and an exterior hall. Used as a house in the past, the mansion was in ruins. It underwent a renovation in 1990 and for a while, it was used as a cultural center. After the completion of its renovation in 2002, it is now functioning as a restaurant (F. 1).

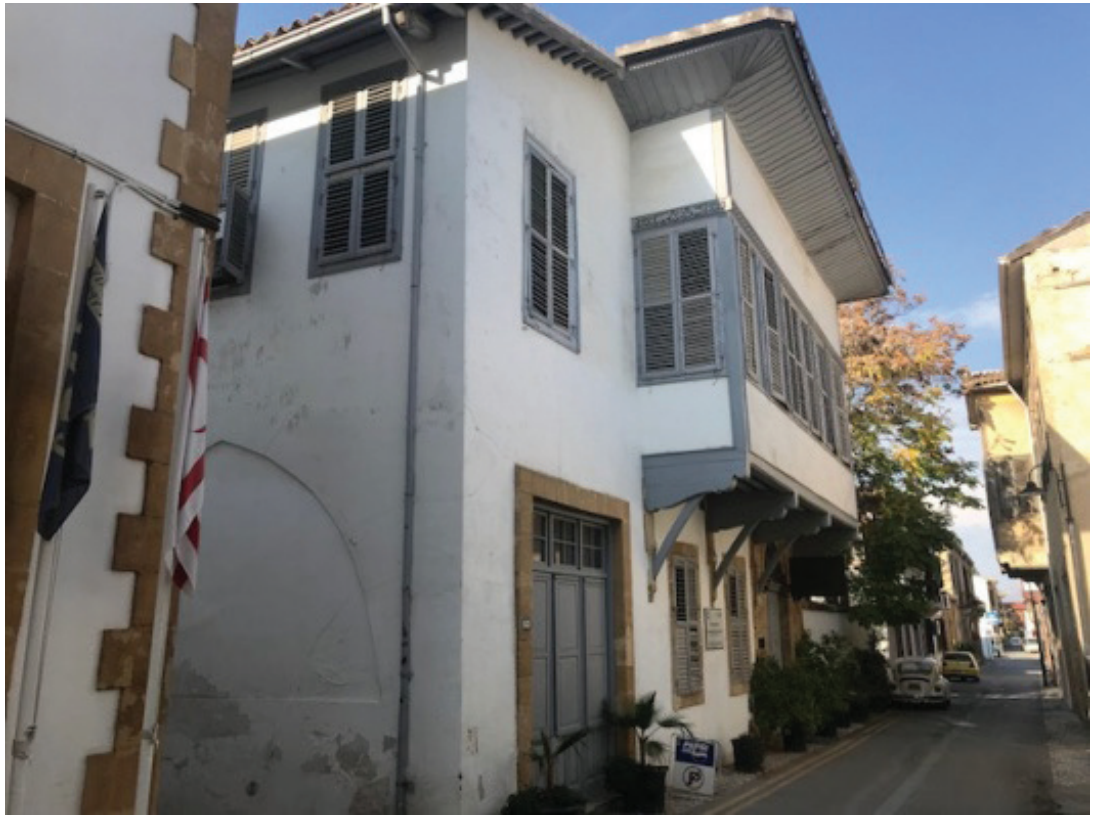

F. 1: Bohcalian Mansion (Koşanlar, 2018)

8 Erhan Amil Balkan, Tarihsel Süreç İçerisinde Kuzey Kıbrıs Türk Cumhuriyetinde Toplum ve Mimarlkk. Mağusa: Doğu Akdeniz Üniversitesi Mimarlık Fakültesi Yayını, 1998), 83; Uğur Ulaş Dağlı, Kıbrıs Sokaklarında Mimariye Yaşama ve Çevreye Dair (Lefkoşa: Işık Kitabevi Yayınları, 1999), 61.

9 Haşmet Muzaffer Gürkan, Dünkü ve Bugünkü Lefkoşa (Lefkoşa: Galeri Kültür Yayınları, 2006), 106; Hizber Hikmetağalar, Eski Lefkoşa'da Semtler ve Anılar (İstanbul: Marifet Yayınları, 1996), 119. 
The Başoda of the mansion is the room in the east of the hall, stretching in the northsouth direction in the shape of an oblong, and has a straight projection to the street in full length. The double-door of the Başoda, in the east of the upper floor hall, is made of wood. There are three panels with profiled edges on each door wing, rhombic shaped and vertically placed. The top and bottom profiles of the panels are curled, while the sides are straight. There are wooden relief motifs between the panels. There is a flower motif between the lower panels and a six-pointed star between the upper panels. There are wooden protruding elements on both sides of the door, inlaid and shaped like a semi-circle. They take a turned shape above the door wings and they merge with the wooden triangular shaped panel stretching to the width of the door, thus forming a bordure surrounding the door. The wooden panel above the headstall of the door is decorated with wooden reliefed circular motifs with a large one in the middle and three small ones on the sides. The panels on door wings facing the Başoda are made of rhombic shapes with curled top and bottom profiles. The wooden panel above the headstall shows a difference from the panel facing the hall with a twelve-point star and a flower motif inside it, and two half-moon motifs above it stretching towards both sides (F. 2).

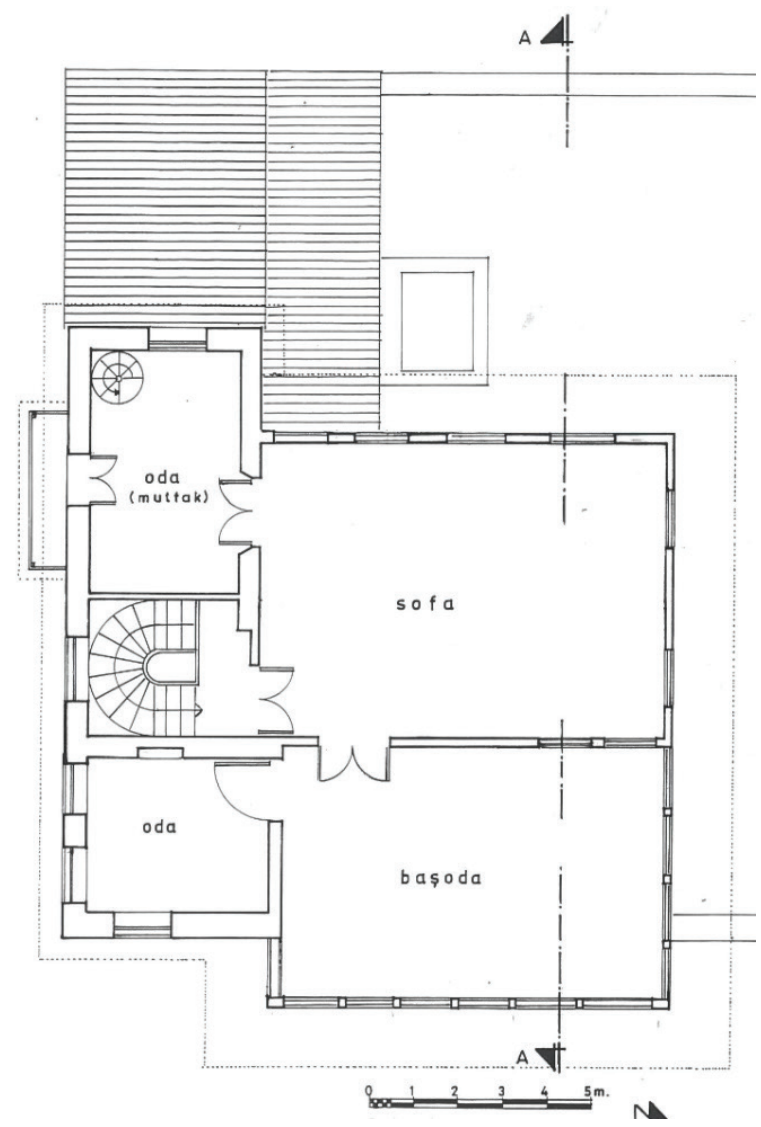

F. 2: Upper Plan of Bohcalian Mansion (Turkan, 1998) 
The room on the south of the Başoda is accessed through a large, one-winged wooden door on the western edge of its south wall. Part of the door, $150 \mathrm{cms}$. from the floor upwards is made of wooden plates and they are shaped with two vertical rectangular panels surrounded by profiled laths. The upper part of the door wing has fixed glass, and this glass is surrounded by profiled laths. The wooden fringes with profiled edges, surrounding the door continue upwards, the upper part of the lintel covered with wood and surrounded by a continuation of door fringes, thus creating a horizontal rectangle to the width of the door. The horizontal fringe above the panel is made of two equal parts forming a triangular shape. A circular shape is made in the middle of the panel, which has a quarter-circle, concave corners, and a relief flower motif placed in it.

Eight windows of the Başoda, six in the east and one each in the north and south face the street, while two windows in the west face the hall, and three other windows in the north face the yard. The windows have three wooden wings, and the ones facing the street and the yard have wooden blinds. Above the lintel line of the windows is made as fixed glass, stretching to the length of the window. These glasses are divided into three equal, horizontal parts with vertically placed two wooden laths each (F. 3).

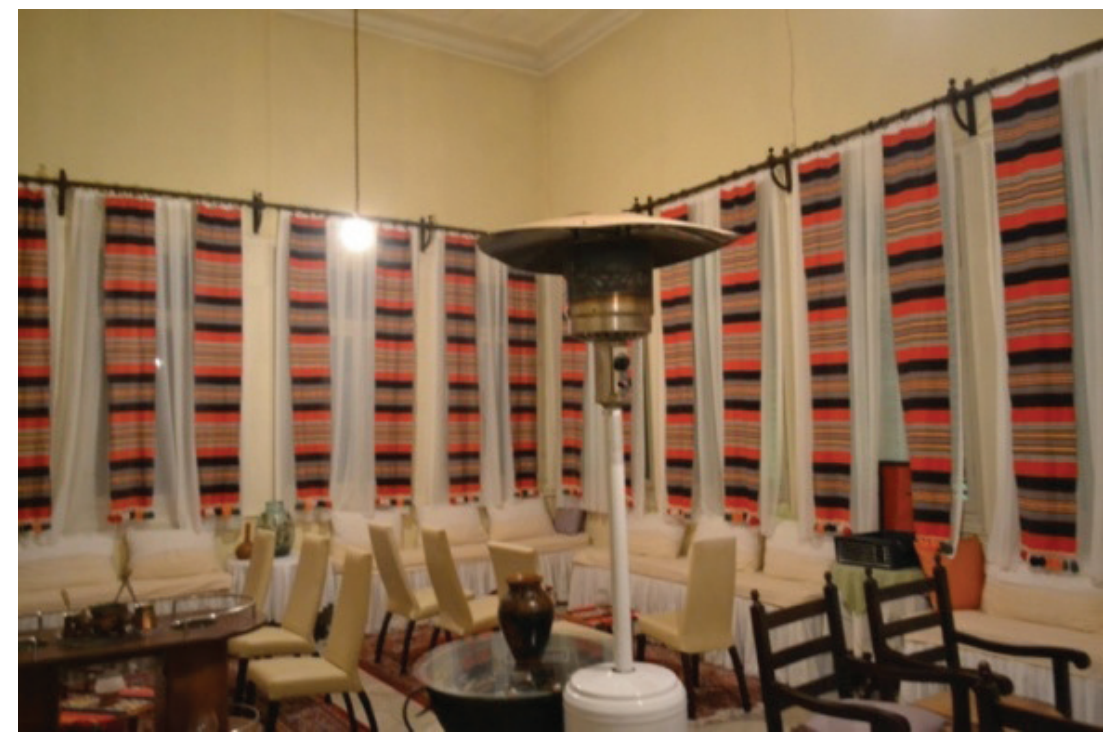

F. 3: Başoda of Bohcalian Mansion (Koşanlar, 2018)

The floor of the Başoda is laid with hexagonal stone plaques and with rhombic ones in between, completing the geometrical order. It is surrounded by stone plaque bordures, parallel to the walls, two lines each on east and west, and one line each on north and south sides, giving a décor to the floor (F. 4). The ceiling is covered with timbers placed in the northsouth direction. The timbers are joined with inlaid thin, wooden sticks, placed in a way to form regularly continuing panels. 
The short sides of each panel are shaped with various curves, thus enriching the décor of the ceiling. The periphery of the ceiling is encircled with fringes, which have inlaid sides. In addition, the ceiling is surrounded by narrower wooden fringes with inlaid lower sides, fixed on the wall. Two wooden, reliefed center-pieces are placed on the ceiling in the shape of eleven-pointed stars, and lighting armatures are hung down on chains from the middle of the center-pieces (F. 5).

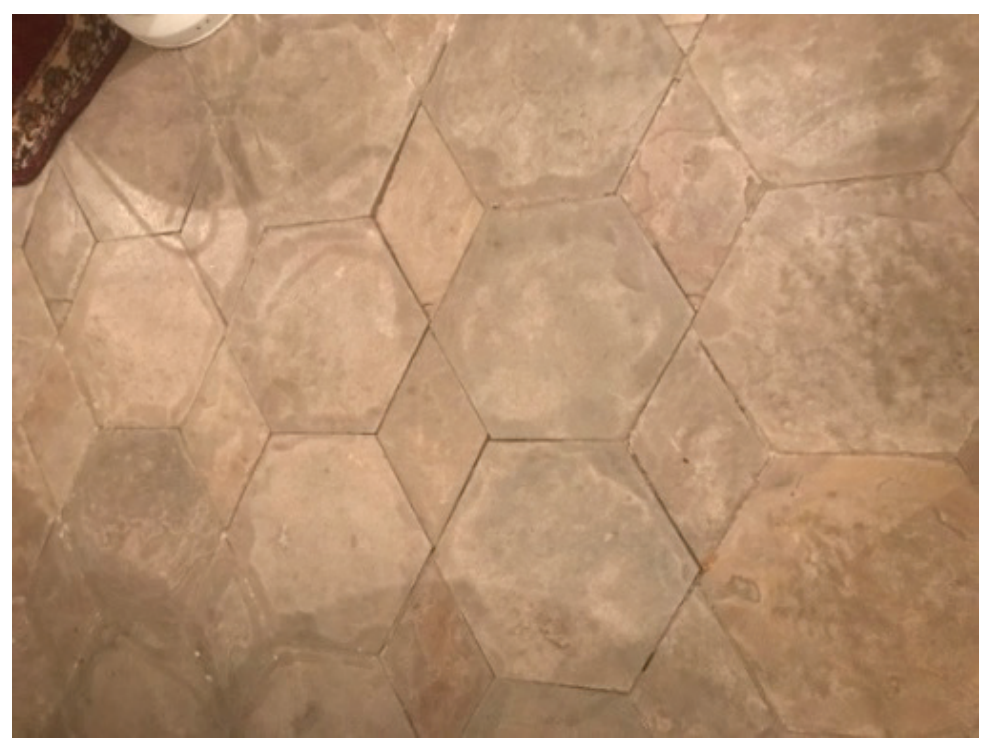

F. 4: Başoda's Floor of Bohcalian Mansion (Koşanlar, 2018)

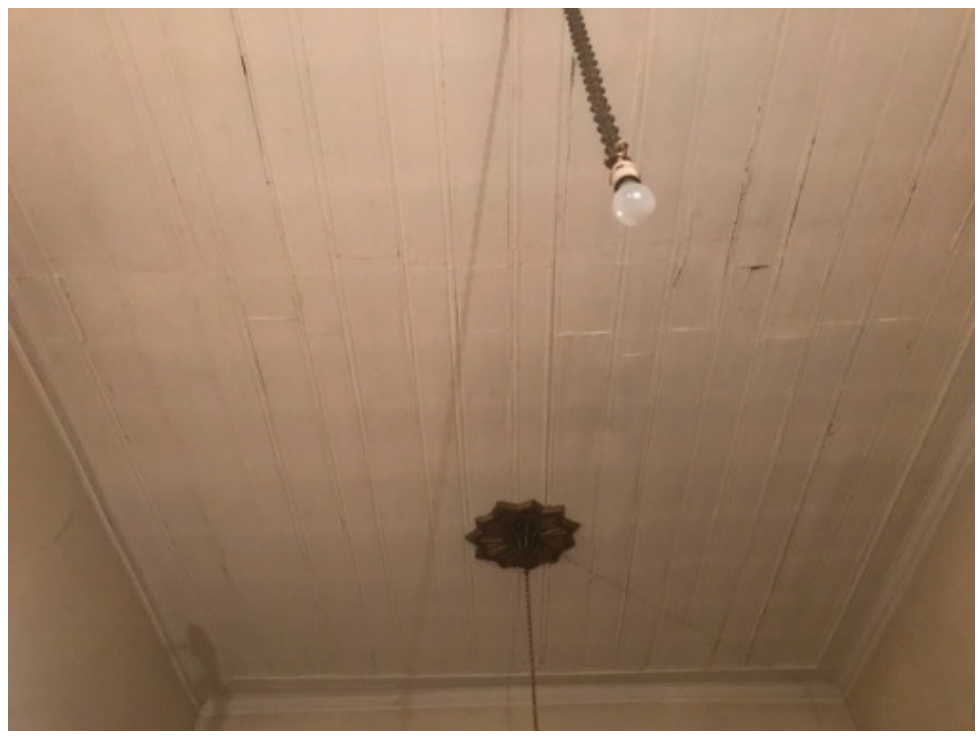

F. 5: Başoda's Ceiling of Bohcalian Mansion (Koşanlar, 2018) 
With its divan and authentic décor, the Başoda is serving as a dining room for private groups today, within the function of the mansion as a restaurant.

\section{3.b. The Eaved House}

Having its name from the wide eaves of the Mainroom, projecting towards the street, and supported by buttresses, the house is at Number 8 on Kütüphane Street of the Selimiye Neighborhood within the walled city of Nicosia. Although the exact date of construction is unknown, some sources date the house to 1850-1860. The date 1932 on its door shows that the house underwent some refurbishment in that year. Being a two-floored house with a yard and an exterior hall plan, The Eaved House was nationalized in 1986, and after the completion of renovations in 1996 it was reopened by the Directorate of Antiquities and Museums as a museum-house for visits and user as a center for culture and $\operatorname{art}^{10}($ F. 6).

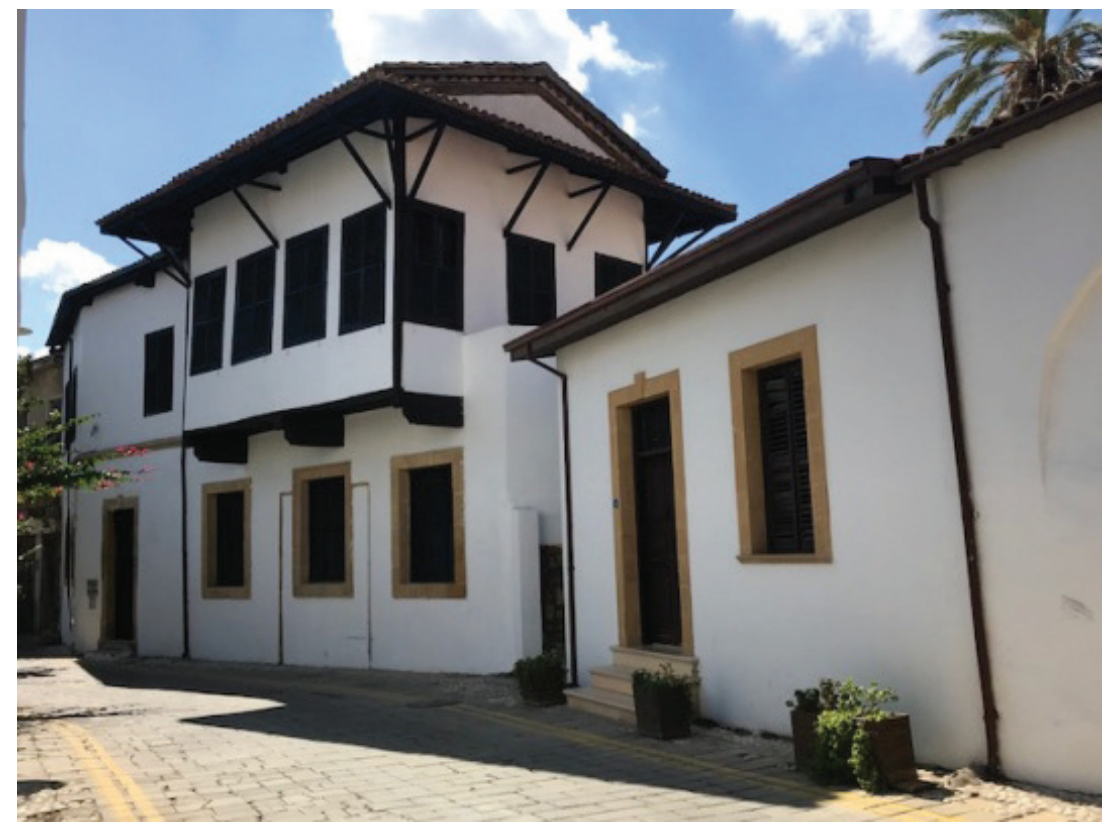

F. 6: Eaved House (Koşanlar, 2019)

The Başoda of the Eaved House is the room on the north side of the upper floor hall and is elevated from the hall with two risers, making a straight projection of the street in the east. This room with a rectangular, almost square-like plan, is reserved for guests being the most advantageous room of the house with its all-around windows, natural light, air, and scenery. The door of the Başoda is made of wood, with two

10 Zihni Turkan, “Kıbrıs’ta İki Müze-Ev Derviş Paşa Konağı ve Saçaklı Ev”, Arredamento Mimarlık 213 (2008), 126-127. 
wings. The door wings are decorated with three vertical rectangular shaped panels on each wing, placed on top of each other, and encircled with profiles (F. 7).

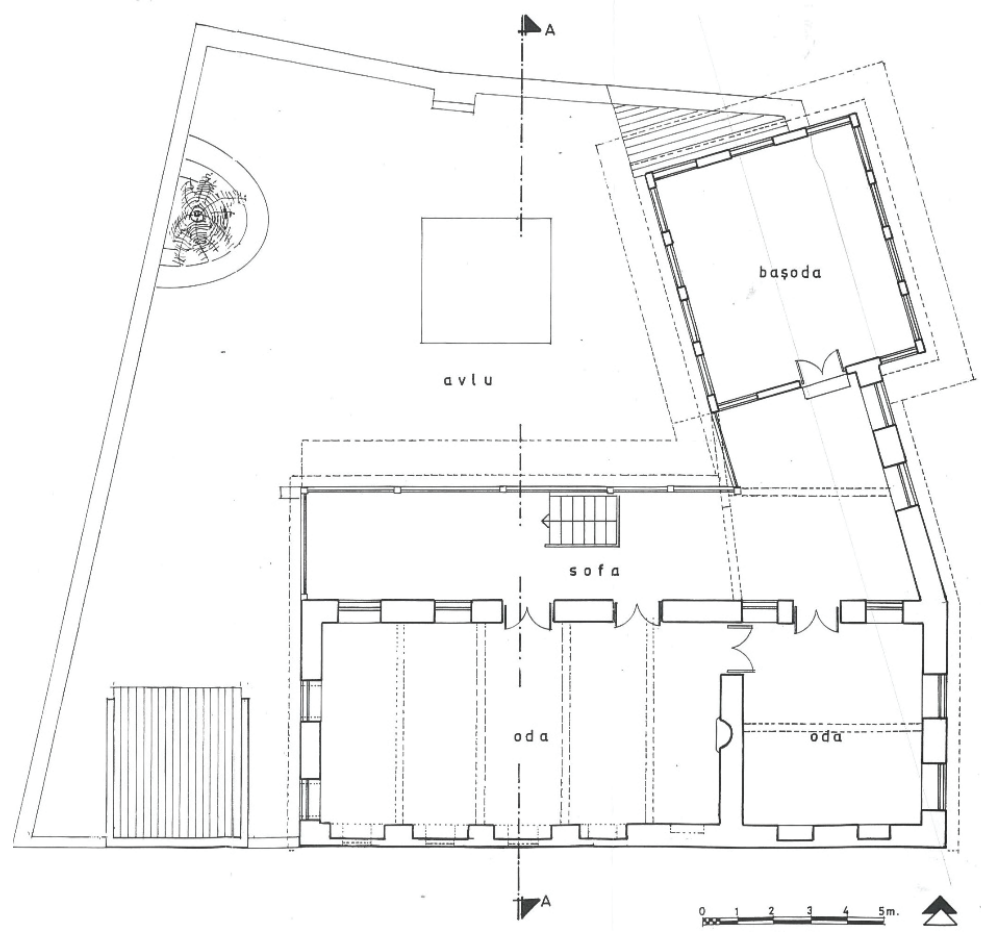

F. 7: Upper Plan of Eaved House (Turkan, 1998)

Four windows of the Başoda on the east side and one each on the north and south, open to the street, while two and 4 windows open to the yard on the north and west sides, and one window on the south side open to the hall. The windows are of guillotine type, with wooden blinds, and are surrounded by wide wooden fringes. The guillotine type wings of the windows are divided into sections by one horizontal and two vertical wooden sticks on each wing, crossing over each other. The window on the west of the door has a wooden system. The system is made of turned timbers, crossing each other vertically and horizontally. On both sides of the door, inside the room, there are wooden lamp shelves, fixed on the wall (F. 8). 


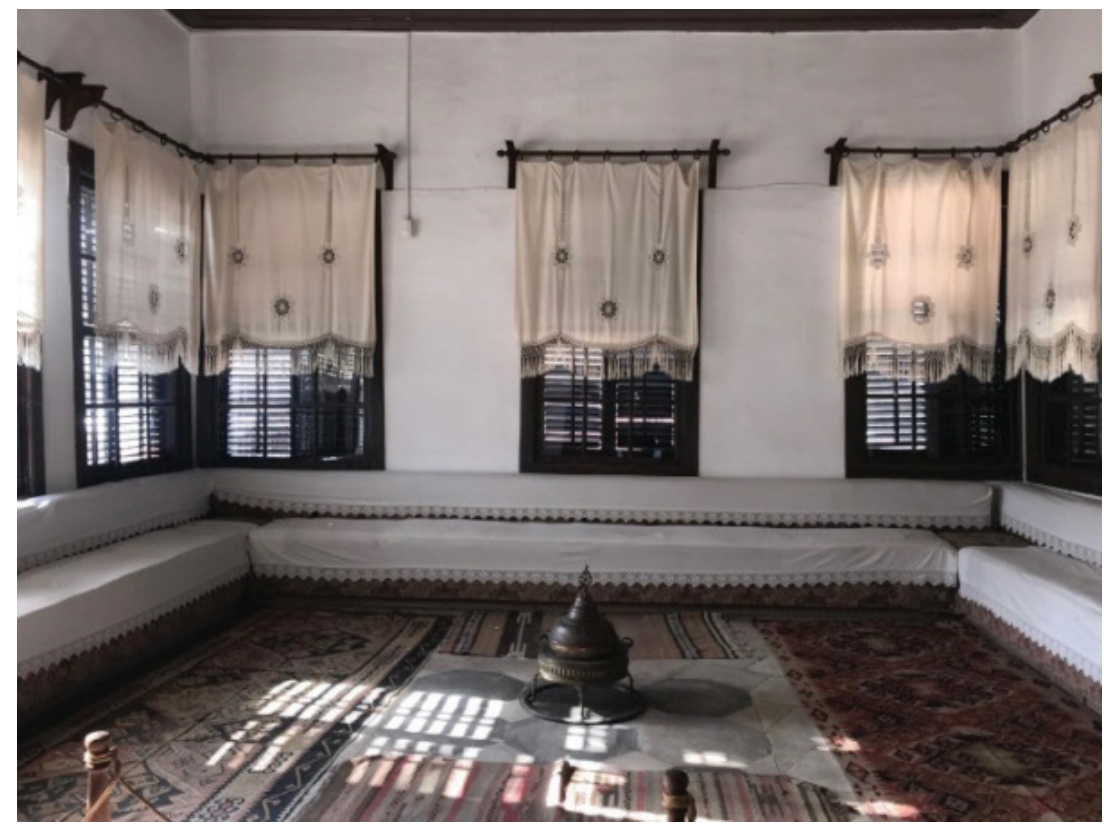

F. 8: Başoda of Eaved House (Koşanlar, 2018)

The floor of the Başoda is covered with almost square-shaped stone plates, laid diagonally, and they are encircled with two lines of stone plates laid alternately. The décor of the floor is enriched with a rectangular center, made with octagonal stone plates complemented with square and isosceles triangular shaped stone plates (F. 9). The ceiling is covered with timber. Having a plain appearance, the ceiling is made with wooden planks placed side by side in the east-west direction. The lap joints of these planks are also covered with wooden sticks. Wall joint laps of the planks are concealed with wooden fringes placed along the length of the room (F. 10). 


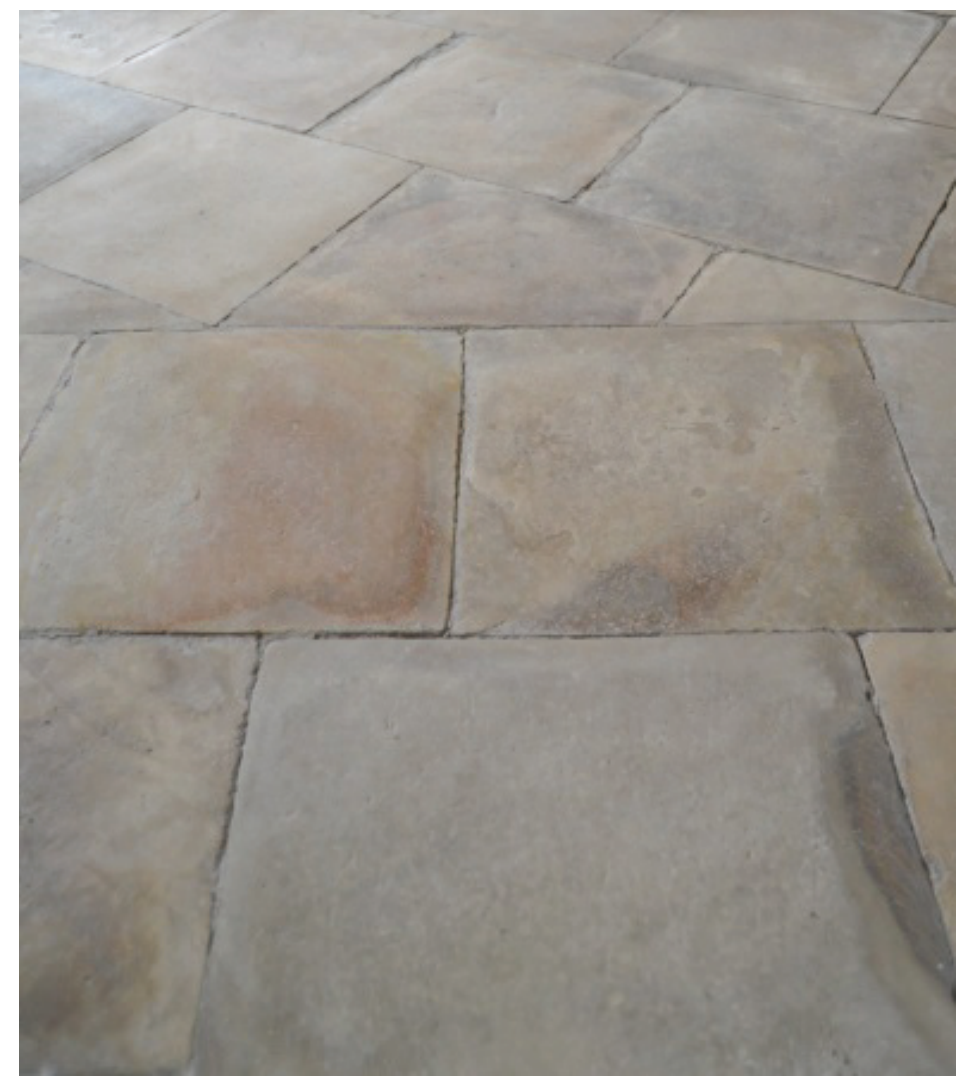

F. 9: Başoda's Floor of Eaved House (Koşanlar, 2018)

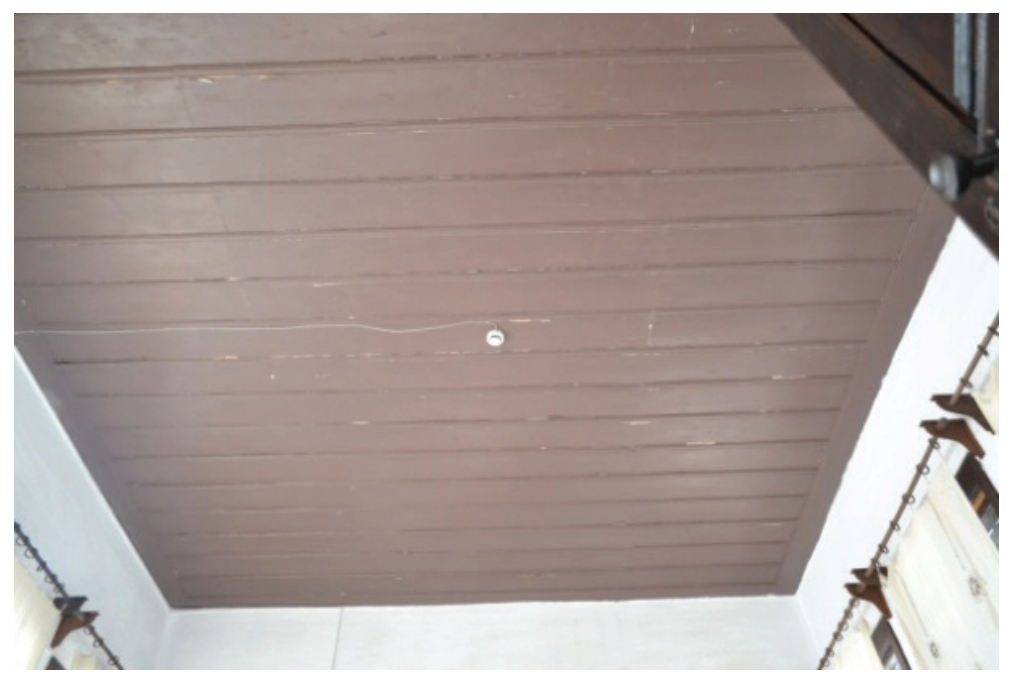

F. 10: Başoda's Ceiling of Eaved House (Koşanlar, 2018) 
At present, the Başoda re-lives its authentic function with divans, surrounding the room in three sides and with embroidered covers, with kilims laid on the floor, and the copper brazier in the middle.

\section{3.c. Derviş Paşa Mansion}

Derviş Paşa Mansion is in Beliğ Paşa Street in the Arabahmet Neighborhood at No. 44-46, within the walled city of Nicosia. Taking its name from its owner Derviş Paşa, the mansion was built in the $19^{\text {th }}$ century in 1801 . This mansion with two floors, a yard, and an exterior hall, is a typical example of a Traditional Turkish House of the Ottoman Period of Cyprus, with all its characteristics ${ }^{11}$. Being in ruins due to bad usage and neglect, the mansion was nationalized in 1975 and renovation had begun in 1979 by the Directorate of Antiquities and Museums. After the completion of renovations in 1986, the mansion was opened on March 21 ${ }^{\text {st }}, 1998$ as an ethnographic museum (F. 11).

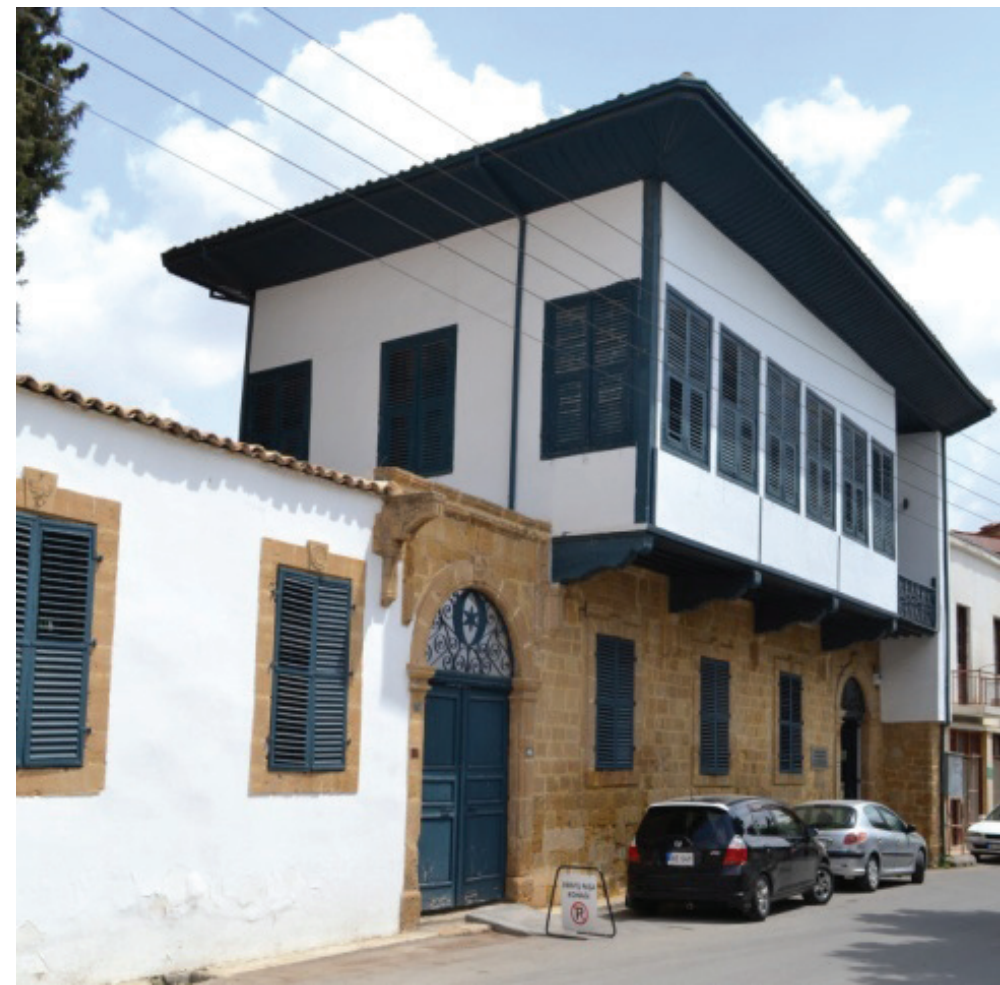

F. 11: Derviş Paşa Mansion (Koşanlar, 2018)

11 Hikmetağalar, Eski Lefkoşa'da Semtler ve Anılar, 118; Anonymous, Lefkoşa Şehri Müze ve Eski Eserleri (Lefkoşa: Kıbrıs Türk Müzelerini ve Eski Eserleri Sevenler Derneği Yayını, 1978), 8; Tuncer Bağışkan, Kıbrıs 'ta Osmanlı-Türk Eserleri (Lefkoşa: Kuzey Kıbrıs Müze Dostları Derneği Yayını, 2005), 364. 
The Başoda of the mansion is the rectangular room on the south of the upper floor hall, making a straight projection towards the street at the length of the room. It is accessed through a double-winged wooden door, elevated from the hall with four risers. The wings of the wooden door of the Başoda, the largest and most splendid room of the mansion, are designed with three vertical rectangular shaped panels each, placed on top of each other. There are wooden reliefed ornaments on these panels; quadrants on the corners, oval in the middle of center panels, and cross-like carved motifs on the top and bottom ones. The top of the door lintel has a horizontally placed wooden panel to the length of the door.

There is a reliefed wooden flower motif in its center. This motif is encircled with a lamp like a shape by carving. There are two rectangular shapes with concave quadrant corners, one on each side of the panel.

The Başoda faces of door wings have vertically placed rectangles placed on top of each other, on each wing. The panel above the door lintel, similar to the hall side, is designed with a reliefed flower motif and horizontally placed reliefed rectangles on each side of the motif (F. 12).

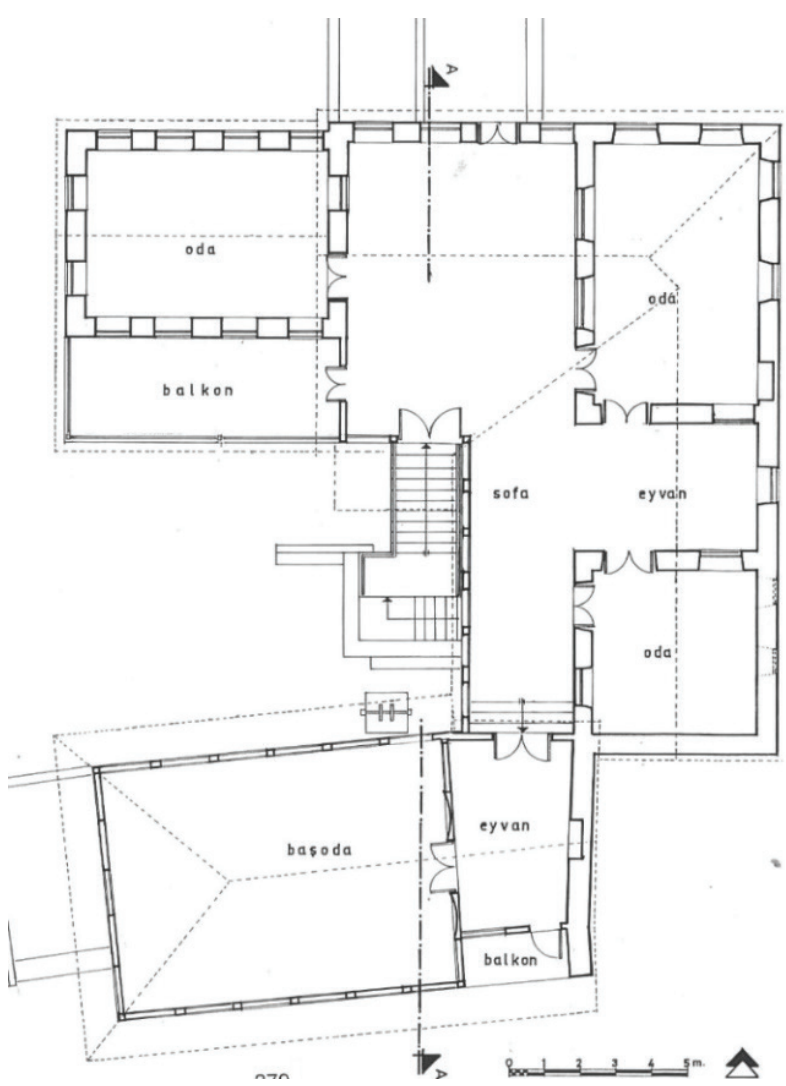

F. 12: Upper Plan of Derviş Paşa Mansion (Turkan, 1998) 
Six windows on the south of the Başoda face the street, three windows on the west and five on the north face the yard, and one window on the east opens into the hall which gives access to the Başoda. The rectangular-shaped windows are guillotine type and with wooden blinds. The guillotine type wings of the windows are divided into squares with wooden sticks going over each other vertically and horizontally. The window on the east side, opening to the hall has a wooden railing. This railing is made of turned timbers standing vertically and horizontally, thus forming rectangular-shaped gaps. On the east end of the north wall, there is a wall niche with three shelves and a double glass wing, which is guessed to be a window opening previously. Ethnographic materials from the period of the mansion are displayed in this niche (F. 13).

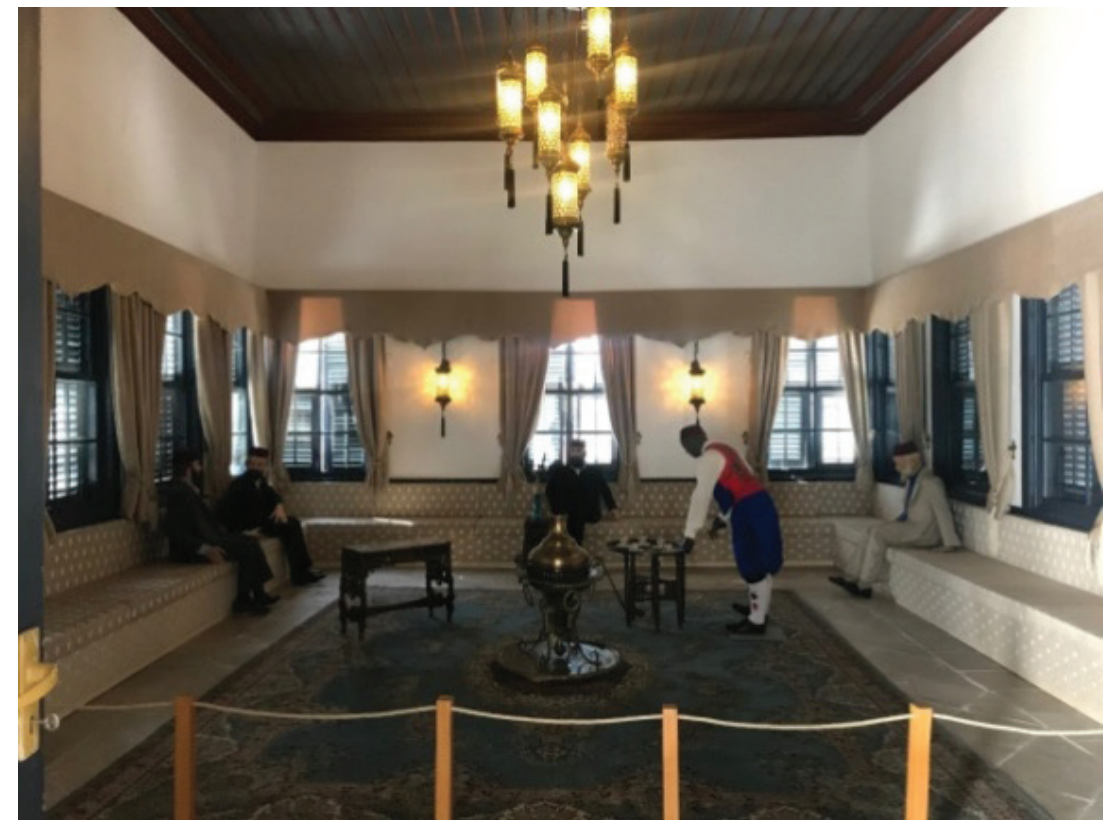

F. 13: Başoda of Derviş Paşa Mansion (Koşanlar, 2018)

On the east side of the Başoda, on both sides of the door, there are lamp or flower niches of a semi-circle plan, about $90 \mathrm{~cm}$. from the floor. The niches have semi-circled kavsaras and are covered with wood. Six cylindrical blocks of woods top and bottom end turned, are lined at equal spaces, placed on the wooden cover and stretching to the kavsara spring line. Vertically shaped rectangular panels with profiled contours are placed inside those spaces. Crowned with three crests, two on the sides and one in the middle, the lower part of the wooden pediment in the direction of the kavsara is made in the shape of a pointed arch. On the left and right sides of the pediment, there are two right triangle panels with their short, right lines in a vertical position. The panels have a wooden reliefed crescent-star motif each (F. 14). 
The floor of the Başoda is covered with square-like stone plates, diagonally placed. The periphery of the floor is bordered with stone plates laid parallel to the walls, thus giving a décor to the floor. The ceiling of the Mainroom is covered with wooden planks. The lap joints of these planks, stretching in the east-west direction, are covered with sticks, and every two sticks are also joined at their ends with sticks again, thus forming repetitious narrow, rectangular panels in the east-west direction. The lines of the ceiling cover joining the walls are surrounded with inlaid wooden fringes; also, a frame was created in the ceiling with inlaid fringes again, after approximately $5 \mathrm{cms}$. The light mounting in the center of the ceiling was placed during the renovation of the mansion in 2016 (F. 15).

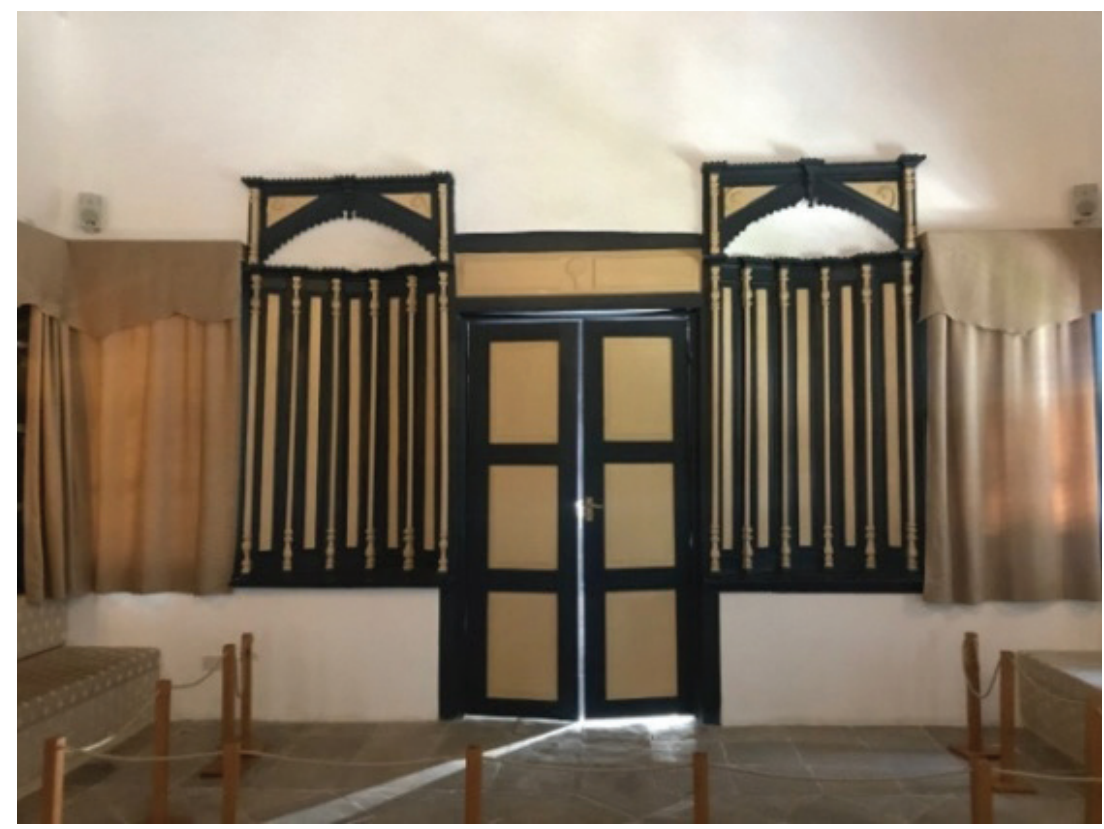

F. 14: Başoda's Niches of Derviş Paşa Mansion (Koşanlar, 2018) 


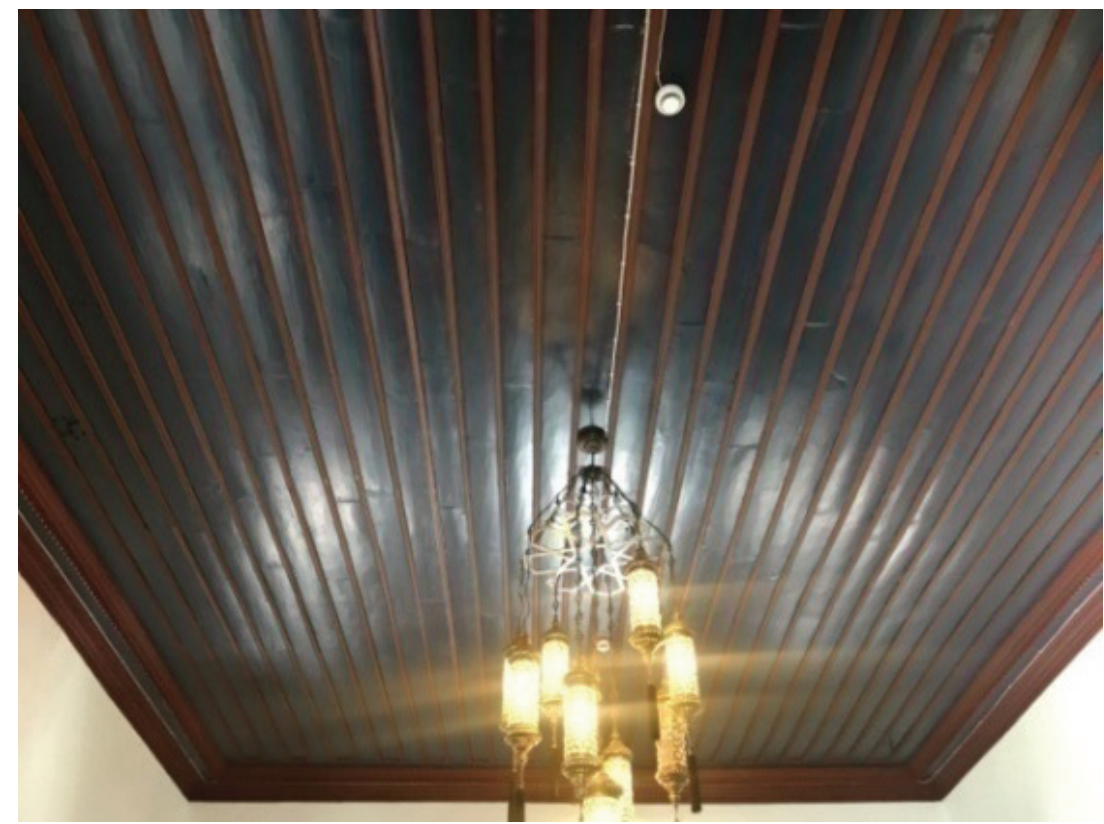

F. 15: Başoda's Ceiling of Derviş Paşa Mansion (Koşanlar, 2018)

At present, the Başoda is furnished with divans and mannequins in an attempt to display the authentic function of the room to the visitors.

\section{3.d. Kadı Menteşoğlu Mansion}

This mansion is at No. 2 on İdadi Street in the Selimiye Neighborhood - one of the important neighborhoods of the walled city of Nicosia - in the north of Selimiye Square. Its date of construction goes back to the Lusignan period, the mansion was built in 1329 as the Palace of Latin Archbishopric. Its upper floor was raised during the Ottoman period and turned into a Turkish House with the addition of an oriel and arrangements in the interior spaces.

After the renovations between 1821 and 1826, the mansion first functioned as the governor's mansion, and later as the office of the mufti ${ }^{12}$. It was used for educational functions between 1925 and 1979, and after the completion of renovations in 1985, it is now being used as the office of the Cyprus Turkish Municipalities Union. This mansion of two floors and a wide yard has an exterior hall play type (F. 16).

12 Anonymous, Kıbrıs’ta Türk Eserleri, 33; Gürkan, Dünkü ve Bugünkü Lefkoşa, 126, 127; Netice Yıldız, "Tarihi Çevre”, KKTC'de Çevre Sorunları Sempozyumu (Lefkoşa: Kıbrıs Türk Mühendis ve Mimar Odaları Birliği Yayını, 1994), 197-206, 204. 


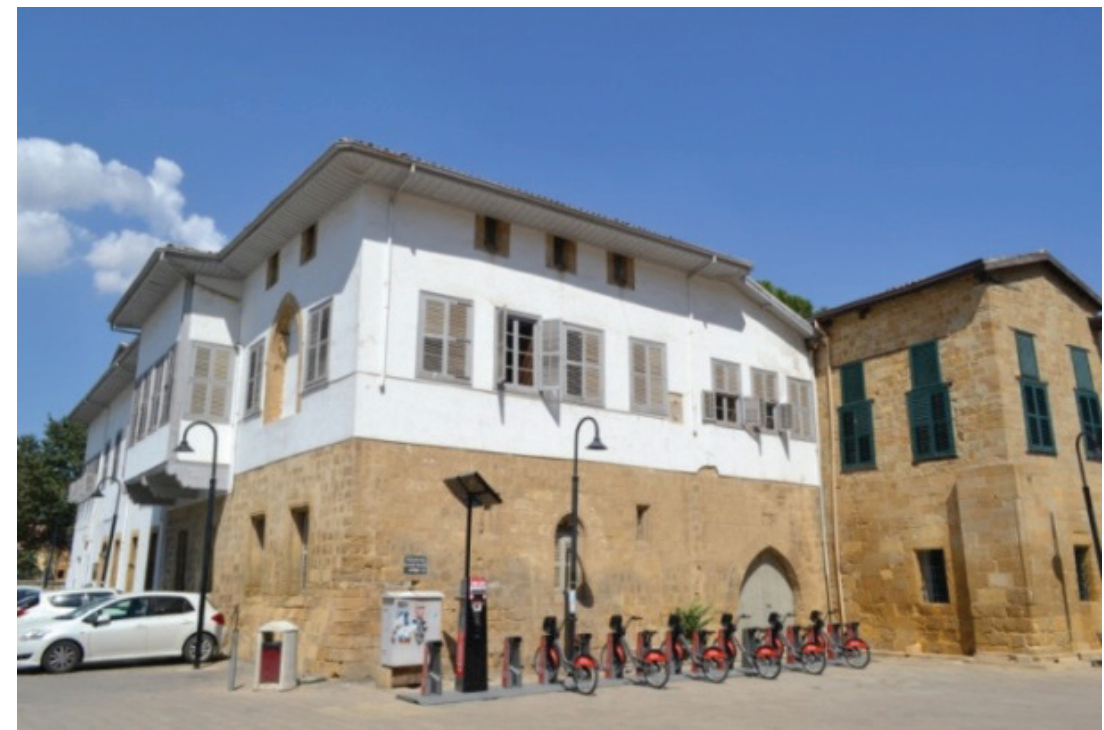

F. 16: Kadı Menteşoğlu Mansion (Koşanlar, 2018)

The Başoda of the mansion is in the southwest corner of the upper floor and faces the historical Selimiye Square of the walled city in the east and south directions. Having a rectangular plan in the east-west direction, the Başoda is the most important room of the mansion with both its position and with its interior fittings and ornamentations. The Başoda is accessed through a wooden two-winged door at the south end of the hall. Through the double-winged wooden door on the east of the north face of the room, the projected room is accessed.

The wings of these doors are made of wooden planks, placed side by side vertically. The wide wooden fringes with profiled edges, surrounding these doors, are continued upwards from the upper levels of the doors, on the wall surfaces above the lintels they form horizontal rectangular panels to the width of the doors. The panel of the Başoda door is made with profiled sticks on a wooden surface, while the panel of the door opening into the room on the north is designed as a wall surface surrounded by profiled sticks (F. 17). 


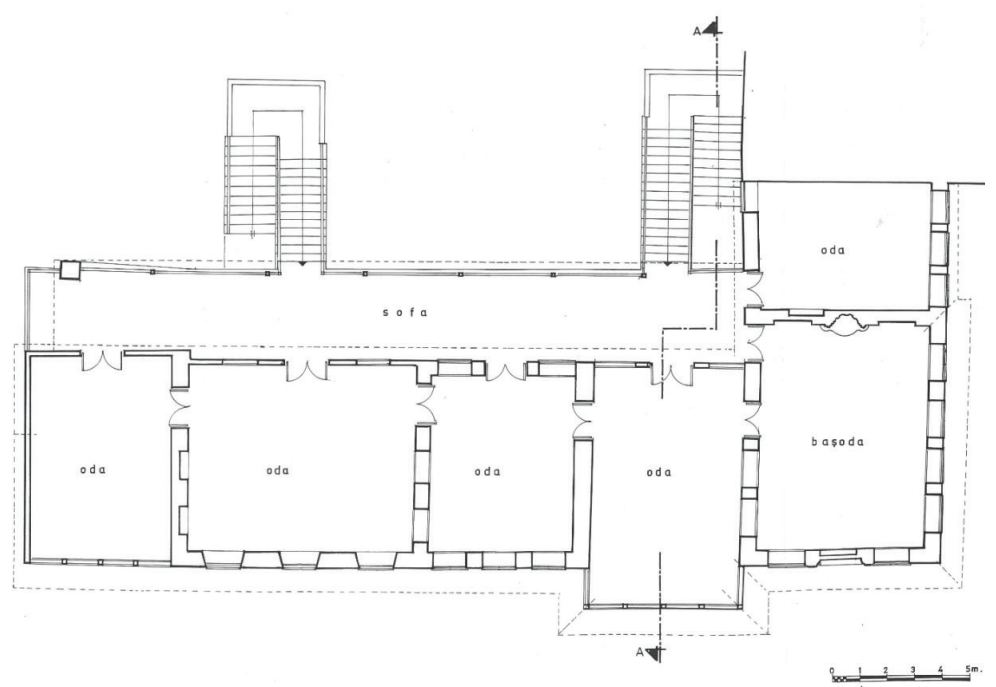

F. 17: Upper Plan of Kadı Menteşoğlu Mansion (Turkan, 1998)

Two of the windows of the Başoda open to the west, and four windows open to the south, into the Selimiye Square. The windows are vertical, rectangular shaped with double wings, with wooden blinds, and have niches on the inside and wooden double covers. The top of the niches is covered with wood. The glass wings of the windows are divided into four vertically place square-shaped sections each with horizontally placed wooden profiled sticks on each wing (F. 18).

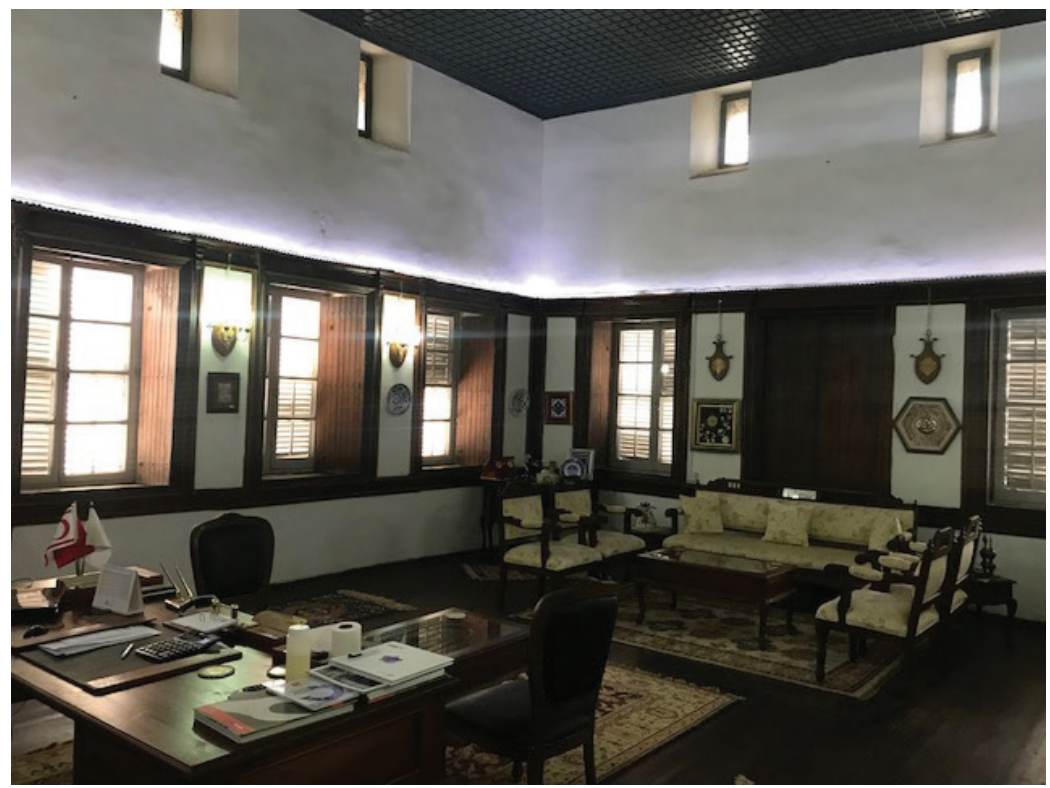

F. 18: Başoda of Kadı Menteşoğlu Mansion (Koşanlar, 2018) 
On the east side of the Başoda, there is a cylindrical niche of a semi-circle plan, about $90 \mathrm{cms}$. from the floor; designed to hold lamps or flowers, and it is quite engraved and decorated. Above the wooden covering of the niche, which has a semi-circle kavsara, nine cylindrical blocks of woods with both ends turned are lined stretching to the spring line of the kavsara. Panels with profiled contours are placed in the spaces between these woods. The bottom part of the wooden pediment in the direction of the kavsara is shaped like a sharp arch. This pediment is crowned with three caps, one in the center and two on each side. Covered with plaster, this surface is painted with vegetable motifs. On the left and right sides of the pediment, two right-triangle panels are placed, with their short, right sides in vertical position. There is a wooden reliefed crescent-star motif on each of the panels. The top part of the lamp niche is carved as an inlaid wooden pediment, and crowned with a headpiece of flower motifs. A semi-circled, overflowing marble is placed in the lamp niche towards the room $(\mathbf{F}$. 19). In the east of the Başoda, on either side of the lamp niche, there is a wall niche between the west looking windows. The niches on the east, in which decorative objects of the period are displayed, have double, glass wings, and three shelves each. The niche on the west side has a wooden cover and stands back to back with the Gothic arched niche on the west front of the mansion.

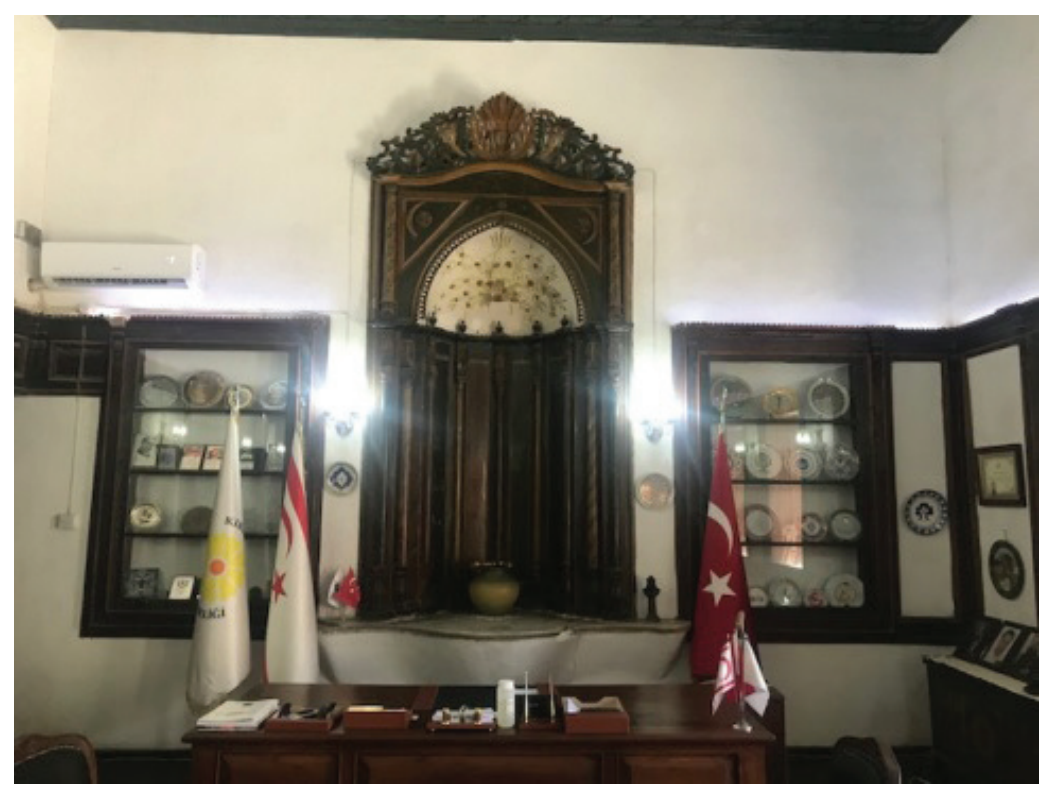

F. 19: Başoda's Niche of Kadı Menteşoğlu Mansion (Koşanlar, 2018)

There are two rectangular-shaped, vertical top windows on the west wall of the room, and three on the south wall. Their top lines are at the same level as the ceiling cover. These top windows have niches facing the room and have wooden lattices. These lattices are formed with wooden sticks placed diagonally (F. 18). 
The wide, wooden fringes stretching at the top and bottom lines of windows and niches, continue up to the lamp niche on the east face, and the gaps are encircled with vertical fringes placed on the sides of windows and niches. The narrow, wooden shelf, its frontal above the fringe stretching on top of the door, window and niches, motifs like lace, surrounds the whole room to the end of the wall niches on both sides of the lamp placed on the east wall of the room. Turned, post-like woods, placed on each side of the windows on the upper level of shelves, form a border to the openings and are completed with a flower motif each, placed gradually downwards. There are wall lamps with motifs, made of iron on wall surfaces between windows, which are placed during the renovation of the mansion.

The floor of the Başoda is covered with timber in the eastwest direction, lined side by side. The most decorated ceiling in the mansion is that of the Başoda. The ceiling is covered in timber and finished with geometrical shapes formed by thin wooden sticks. The ceiling is divided into two sections; the west section being a square, and the east section a rectangle. The squared-shaped section of the ceiling is decorated with thin, wooden sticks by forming small squares, the north and south ends of the section finished with a line of rhombuses each, made of wooden sticks. A wooden, square centrepiece is placed in the middle of this section, surrounded by profiled wooden fringes.

There is a circle in the middle of this centrepiece, formed of rhombuses and triangles. The periphery of this circle is also decorated with rhombus and triangle shapes. The section of the ceiling to the east is decorated with nested octagonal shapes made of wooden sticks. The decoration is enriched by placing a square shape in each octagon. The two sections of the ceiling are separated with wooden fringes (F. 20).

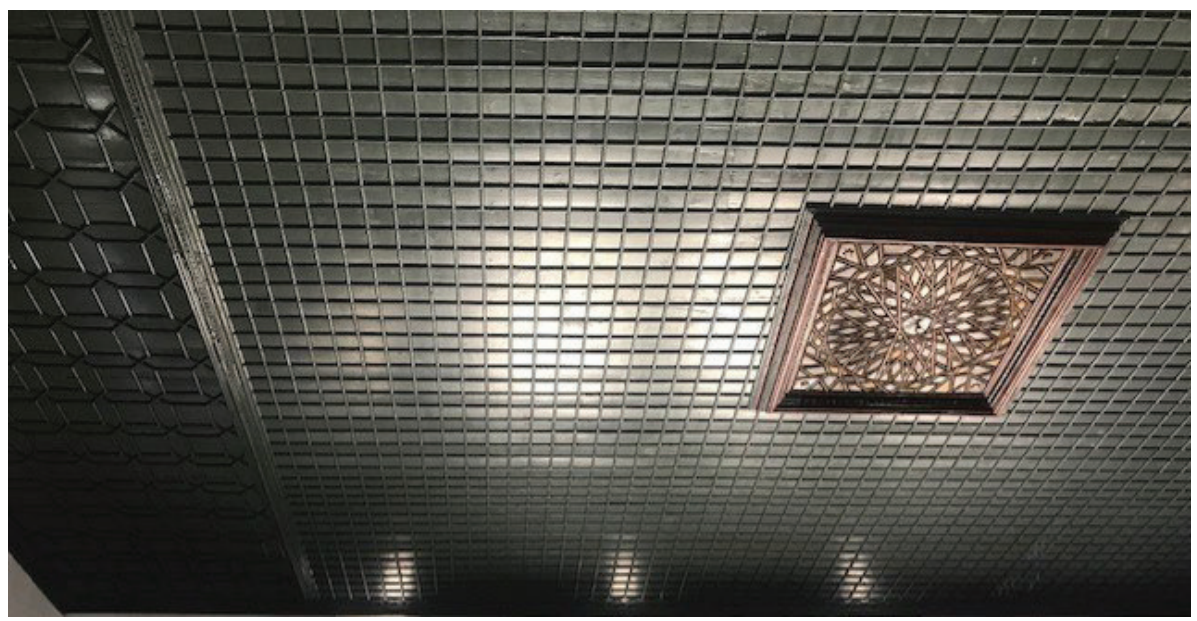

F. 20: Başoda's Ceiling of Kadı Menteşoğlu Mansion (Koşanlar, 2018) 
At present, the Başoda is functioning as the office of the President of the TRNC Union of Municipalities Center.

\section{3.e. Küçük Mehmet Buildings}

This mansion is at number 28 within the historical texture of Selimiye Square, in the Selimiye Neighborhood of the walled city of Nicosia. The construction of the mansion is dated back to 1326, during the Lusignan Period. Designed as an administrative building for the clergy, the building was turned into a Traditional Turkish House during the Ottoman Period of Cyprus by the addition of upper floor annexes, an oriel, and interior space alterations ${ }^{13}$. The mansion was used for various functions throughout its history and underwent renovations in 2004 and 2014. After the last renovation by the Directorate of Cyprus Waqfs, it is now functioning as the Nicosia Branch of the Yunus Emre Waqf (F. 21).

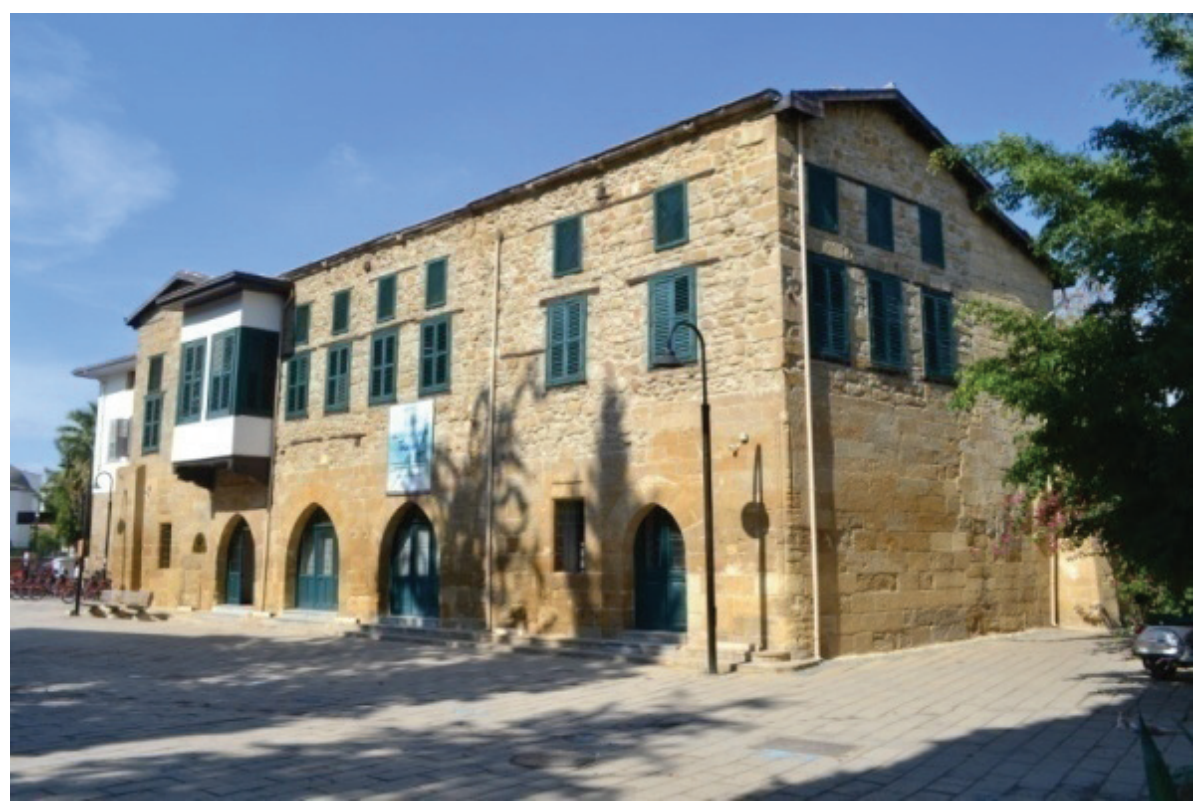

F. 21: Küçük Mehmet Buildings (Turkan, 2018)

The Başoda of the house is on the upper floor, on the southwest corner, overlooking Selimiye Square. The rectangular planned room in the north-south direction is accessed from the hall through a double-winged wooden door. The door wings are shaped with two vertical, rectangular panels, side by side and both at the top and the bottom, and one horizontally placed rectangular panel in the middle, on each wing. The lower panels are shorter than the ones on top. There are six rectangular-shaped,

13 Zekai Altan, Gizemli Kıbrıs (Lefkoşa: Ateş Matbaacılık Yayını, 2006), 390. 
double wooden winged windows with wooden blinds on the east, west, and south sides of the Başoda, two on each side. (F. 22).

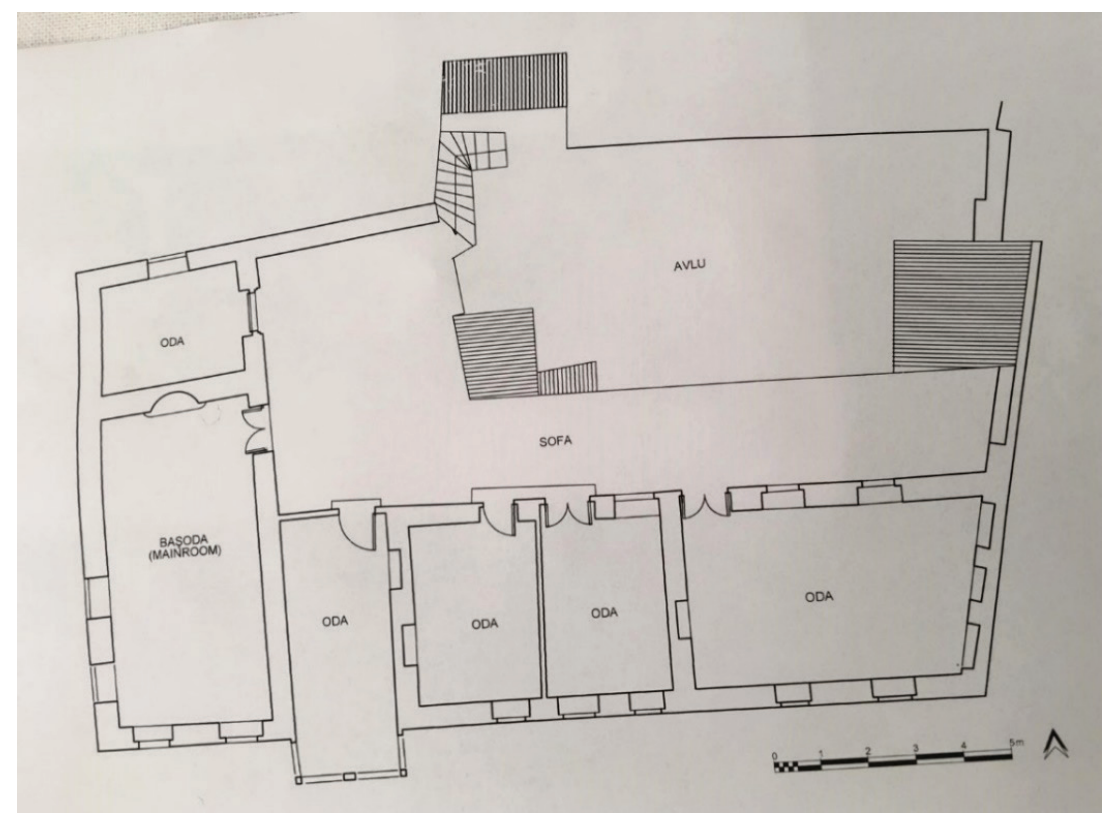

F. 22: Upper Plan of Küçük Mehmet Buildings

(From Antiques and Museums Department of TRNC)

The windows on the west and south open to Selimiye Square. Previously opening to the hall iwan, the windows on the east are at present turned into cupboard niches with shelves and wooden covers. Above all the windows there are vertically placed rectangular skylights with niches facing the room, and they are narrower than the windows. The skylights are latticed, and these lattices are made with diagonally placed sticks. The niche upper levels of skylights are wooden. There are wall lamps on wall surfaces, made of iron (F. 23). 


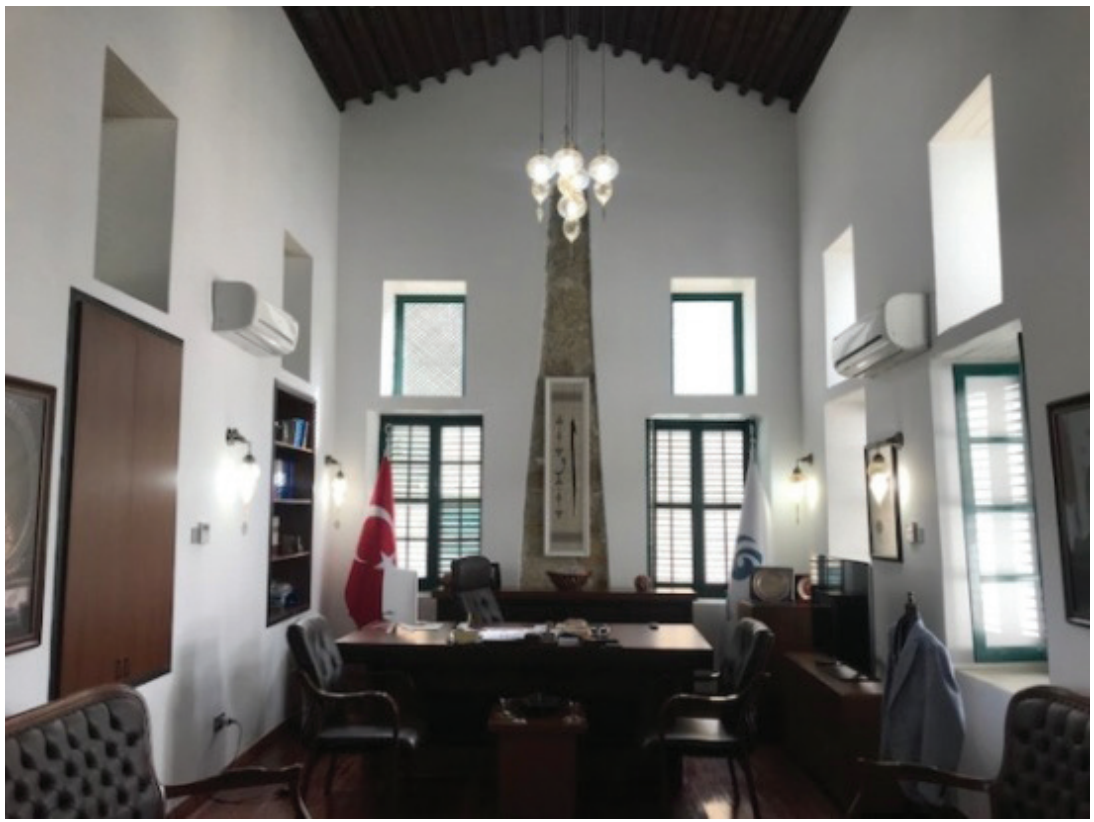

F. 23: Başoda of Küçük Mehmet Buildings (Turkan, 2018)

There is a cylindrical, semi-circle planned niche on the north face of the Başoda known as a lamp or flower niche. This niche of semi-circle arched kavsara, is wood covered. Above the cover and on both corners of the kavsara triangles are formed with profiled sticks, and crescent-star motifs are placed inside the triangles as wooden reliefs. The top of the skylights is also shaped with curvilinear lined motifs. Above that, a large wood reliefed flower motif is placed, with two smaller ones on each side. There are turned woods shaped like bollards, two on each side of the niche up to the kavsara, and one on each side of the kavsara. Of these woods, the outer ones on the sides of the niche are protruding from the wall surface. Five more wooden crowns are placed side by side at the same level with the crowns, and produced in the same shape, on the niche surface between the turned woods. Four vertical, rectangular shaped panels are created between these crowns. The bottom of the niche is designed as protruding from the wall, like a conical console, and two colored marble plates are placed on this console (F. 24). 


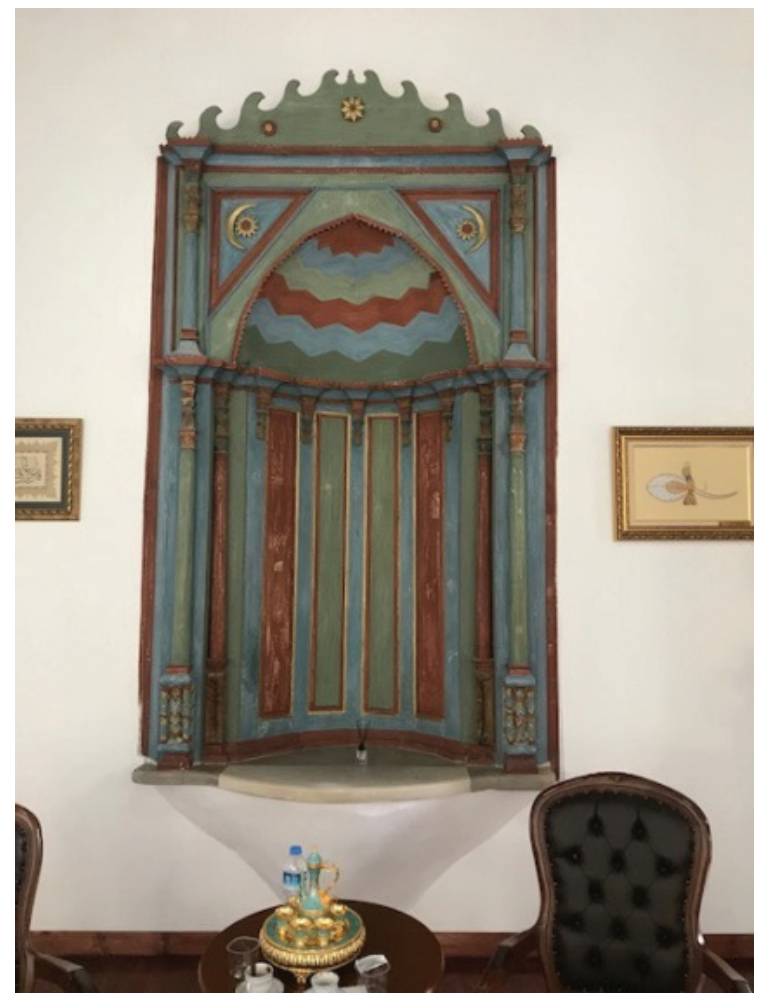

F.24: Başoda's Niche of Küçük Mehmet Buildings (Turkan, 2018)

The floor of the Başoda is covered with wooden planks placed side by side (F. 25.a). The ceiling is without a cover and its structure is made of cylindrical wooden beams placed side by side, carried on two wooden trusses in the east-west direction, supported by C-S curved wooden consoles. The cylindrical beams are covered with east-west aligned woods. A chandelier type lighting armature is hung on each of the axles of the wooden trusses (F. 25.b). At present, the Başoda is being used as the administrative office of the waqf. 


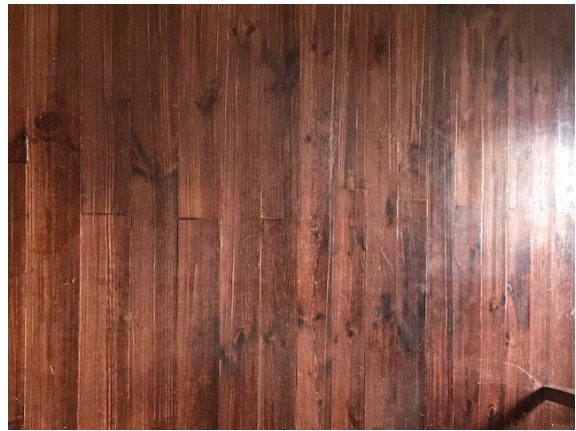

F. 25.a: Başoda's Ceiling of Küçük Mehmet Build. (Koşanlar, 2018)

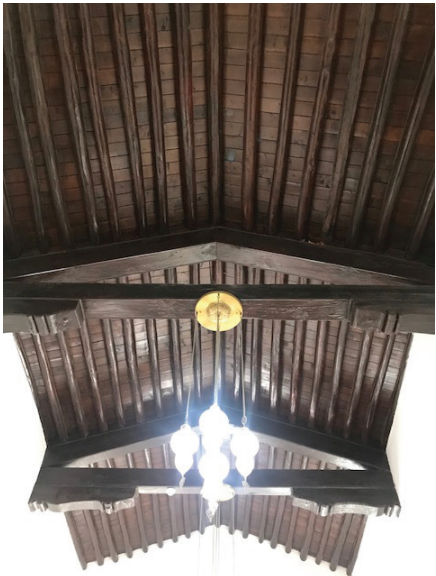

F. 25.b: Başoda's Ceiling of Küçük Mehmet Build. (Koşanlar, 2018)

\section{Conclusion}

Shaped by the Turkish life culture, Traditional Turkish Houses form an important architectural heritage in all geographical areas that came under Ottoman rule, connecting the past to the present with all their characteristics. Designed and decorated with the importance given to guests, Başoda constitutes the most important space of the Turkish House with the qualities of internal elements. Leaving a mark in the historical city texture of capital Nicosia, $19^{\text {th }}$ century Turkish Houses of the Ottoman Period architectural works still reflect and keep alive the Turkish life culture to their visitors. Research and onsite observations carried out on the selected Nicosia Turkish Houses, which have been renovated, reveal the value given to guests in Turkish life culture reflected in the planning of the house, and the authentic interior design of the Başoda shows that it is the most important room of the Traditional Turkish Houses. The Başodas of the Nicosia Turkish Houses within the scope of this research were designed either on a corner of the house facing the street or a square depending on the position of the house or as the room with a projection overlooking the street. The Başodas have been designed as the most advantageous room of the house by getting plenty of sunshine, natural air, and scenery with numerous windows on three sides of the projection, and windows and top windows opening to both sides in the corner rooms. Being the largest room of the house, the Başoda is generally of a rectangular plan and is usually raised from the hall with a threshold or steps, thus emphasizing its importance in the house.

Having a different interior design compared to the other rooms of the house with its material, form, and ornamentations, the privilege of the Başoda begins at its door. The wings of the wooden double door are decorated with wood reliefed motifs and with panels of various geometrical shapes and profiled edges. Başoda windows are 
rectangular, with two wings, wooden blinds, and surrounded by wide wooden fringes of profiled edges. The fringes are continued between windows horizontally, thus forming panels on wall surfaces. Narrow, wooden shelves taking place at the upper level of windows, stretch horizontally along the façades of the room, creating an upper line.

The inlaid niches, named as lampstands or flower stands, make up an important interior element of Başodas. These semi-circle planned niches with semi-circle kavsaras are covered in wood, and the covering is divided into sections and framed with turned woods. The lampstand (flower stand) niches with marble plates placed inside are crowned with wooden tops worked with various motifs. Painted with various colors, the niches are almost the symbols of Başodas.

Başoda floors are either covered with painted and polished wooden planks placed side by side, or covered with stone plaques of different geometrical shapes, which are local materials. The stone plaques are either laid diagonally or alternately, and their perimeters are framed with lines of stone plaques parallel to the walls, thus giving a décor to the floor. Sometimes the décor is enhanced by making a centrepiece in the middle, using stone plaques of different shapes.

The ceilings are generally wood covered and their lap joints are covered with thin profiled sticks and completed with a wooden center piece, decorated with either carved, or reliefed motifs. The ceiling and wall joints are surrounded by wooden fringes with profiled edges. The rectangular-shaped ceilings are divided into two as square and rectangle and decorated. These two sections of the ceilings are divided and framed with wide, wooden fringes.

Similar to other countries, Başodas in the renovated Turkish Houses of Nicosia are functioned at present befitting their authentic identities. With its exclusively designed and produced interior elements, the most important room of the Traditional Turkish Houses reserved for guests, the Başoda stands as an important characteristic transmitting Turkish life culture from the past to the future and keeps alive the architectural cultural heritage of the Turkish people.

Peer-review: Externally peer-reviewed.

Conflict of Interest: The authors have no conflict of interest to declare.

Grant Support: The authors declared that this study has received no financial support.

Hakem Değerlendirmesi: Dış bağımsız.

Çıkar Çatışması: Yazarlar çıkar çatışması bildirmemiştir.

Finansal Destek: Yazarlar bu çalışma için finansal destek almadığını beyan etmiştir. 


\section{Kaynakça/References}

Altan, Zekai. Gizemli Kıbrıs. Lefkoşa: Ateş Matbaacılık Yayını, 2006.

Anonymous. Kıbrıs 'ta Türk Eserleri. Lefkoşa: Kıbrıs Türk Federe Devleti Eğitim, Gençlik, Kültür ve Spor Bakanlığı Eski Eserler ve Müzeler Dairesi Müdürlüğü Yayını, 1982.

Bağışkan, Tuncer. Kıbrıs'ta Osmanlı - Türk Eserleri. Lefkoşa: Kuzey Kıbrıs Müze Dostları Derneği Yayın1, 2005.

Balkan, Erhan Alim. Tarihsel Süreç İçerisinde Kuzey Kıbrıs Türk Cumhuriyetinde Toplum ve Mimarlık. Mağusa: Doğu Akdeniz Üniversitesi Mimarlık Fakültesi Yayını, 1998.

Bektaş, Cengiz. Türk Evi. İstanbul: Yapı Kredi Yayınları, 1996.

Dağlı, Uğur Ulaş. Kıbrıs Sokaklarında Mimariye Yaşama ve Çevreye Dair. Lefkoşa: Işık Kitabevi Yayınları, 1999.

Eldem, Sedad Hakkı. Turkish House Ottoman Period I. İstanbul: Türkiye Anıt Çevre Turizm Değerlerini Koruma Vakfı Yayını, 1984.

Eldem, Sedad Hakk1. Turkish House Ottoman Period III. İstanbul: Türkiye Anıt Çevre Turizm Değerlerini Koruma Vakfi Yayını, 1987.

Gürkan, Haşmet Muzaffer. Dünkü ve Bugünkü Lefkoşa. Lefkoşa: Galeri Kültür Yayınları, 2006.

Hasol, Doğan. Ansiklopedik Mimarlık Sözlüğü. İstanbul: Yapı-Endüstri Merkezi Yayını, 1993.

Hikmetağalar, Hizber. Eski Lefkoşa'da Semtler ve Anılar. İstanbul: Marifet Yayınları, 1996.

Kuban, Doğan. Türk Hayat’lı Evi. İstanbul: T.C. Ziraat Bankası Kültür Yayını, 1995.

Küçükerman, Önder. Kendi Mekânının Arayışı İçinde Türk Evi. İstanbul: Türkiye Turing ve Otomobil Kurumu Yayını, 1991.

Küçükerman, Önder ve Şemsi Güner. Anadolu Mirasında Türk Evleri. İstanbul: T.C. Kültür Bakanlığı Yayınları, 1995.

Lefkoşa Şehri Müze ve Eski Eserleri. Lefkoşa: Kıbrıs Türk Müzelerini ve Eski Eserleri Sevenler Derneği Yayını, 1978.

Salvator, A. Louis. Kıbrıs'ın Başkenti Levkosia. Çevirmen Vur Yektaoğlu. Lefkoşa: Galeri Kültür Yayınları, 2012.

Turkan, Zihni. “Kıbrıs'ta İki Müze-Ev Derviş Paşa Konağı ve Saçaklı Ev”, Arredamento Mimarlık 213 (May1s 2008): 124-127.

Turkan, Zihni. "The Place of Turkish Culture of The Life in Housing Design: Example of Turkish Houses in Cyprus During the Ottoman Period". The Turkish Online Journal of Design, Art and Communication 6/3 (July 2016): 343-350.

Yıldız, Netice. “Tarihi Çevre”. KKTC'de Çevre Sorunları Sempozyumu (17-18 Şubat 1994). Lefkoşa: Kıbrıs Türk Mühendis ve Mimar Odaları Birliği Yayını, 1994, 197-206.

Yürekli, Hülya ve Ferhan Yürekli. Türk Evi Gözlemler-Yorumlar. İstanbul: Yap1 Endüstri Merkezi Yayın1, 2005. 
